\title{
1800’lerin Küresel Krizleri, Büyük Depresyon ve 2008 Krizi
}

\author{
Mustafa Emre AKBAŞ*
}

Öz

Finansal krizler dünya ekonomik düzenini sarsan afetlerdir. Bu afetler toplumların yaşam standartlarını da etkilemektedir. 18. yy.'dan itibaren ulus devletlerin ortaya çıkışı ulusal ekonomileri de birbirine yakınlaştırmıştır. Karşılıklı ticaret ve buna bağlı finans ilişkilerin de artması ulusal para ve finans kurumlarını da birbiri ile olan bağlantılarını hızlandırmıştır. Fakat dönemin Klasik öğreti anlayıșı par ve finans piyasalarını düzenleyecek ve denetim altında tutacak yetkili kurumları oluşturamamıştır. Bu yüzden 20. yy. kadar finansal krizler daha sık aralıklarla yaşanmıştır. 1930 sonrası Büyük Depresyon ve Keynesyen Devrim yetkili ulusal para kurumları olan Merkez Bankalarına müdahale yetkilerini vererek ulusal para ve finans sahalarını düzenlemeleri için tecrübe kazanmalarına olanak sağlamıştır. 20 yy. içinde yaşanan finansal krizler ise ağırlıklı iki nedenden dolayı ortaya çıkmaktadır. Birincisi küresel para ve finans sistemine hakim ülkenin hatalı para ve finans politikaları sonucunda çevresindeki ülkeleri de içine alacak şekilde ortaya çıkmaktadır. Íkincisi ise serbest dolaşımlı küresel finans akımlarının düzensiz dağılımı ve yükselen Pazar ekonomilerindeki kontrolsüz dalgalanmayla krizlerin çıkmasıdır. Çalışmanın hedefi finansal krizler öncesinde yaşanan iktisadi süreçlerin incelenmesi ve bu krizlere ne tür toplum ekonomisi hareketlerinin neden olabileceğini ortaya çıkarmaktır. Olası finansal krizlere karşı nasıl hazır olunabileceği konusu da aynı zamanda tartışılacaktır.

Anahtar Kelimeler: Finansal Krizler, Uluslararası Para Düzeni, Küresel Krizler, Büyük Depresyon, 2008 Krizi

Jel Sinıflaması: G01,E32,F02,E42

Global Crises of the 1800s, Great Depression and 2008 Crisis

\begin{abstract}
The financial crisis are the disasters that the world economic order have convulsed. These disasters were affected infinitely the social living standarts. The

Özgün Araştırma Makalesi (Original Research Article)

Geliş Tarihi: 22.07.2016 Kabul Tarihi: 06.12.2016

DOI: http://dx.doi.org/10.17336/igusbd.305553

*Yrd. Doç. Dr., Marmara Üniversitesi İktisat Fakültesi İktisat Bölümü, İstanbul, Türkiye, E-posta: emreakbas@marmara.edu.tr
\end{abstract}


Sayfa/Page | 78

İGÜ Sos. Bil. Derg.,

4 (1), 2017, ss. 77-127.

emergence of the nation state from the 18th century, national economies are also closer together. Bilateral trade has accelerated and connections with each other as well as with financial institutions to increase the national currency and the related financial relationships. But the era of the classical doctrine understanding money and to regulate financial markets and to keep under control could create the appropriate authorities. So 20th Century up to the financial crisis were experienced more frequently. After the Great Depression and the Keynesian Revolution in 1930 by the competent national monetary authorities, the Central Bank has the authority to intervene to allow them to gain experience in the field of national monetary and financial arrangements. 20 yy. Financial crises are emerging in the mainly two reasons. First, global currency and the surrounding countries as a result of faulty monetary and financial policy of the country is emerging to dominate the financial system to include as well. The second is the free circulation of the current global financial crisis with irregular distribution and the emergence of uncontrolled fluctuations in emerging market economies. The object of this work is study and resarch the ecomoic process before the financial crisis and to reveal which social economic affairs are the reasons for financial crisis. Add to this object it will be discussed how the financial actors can be on the alert towards the potential financial crisis.

Keywords: Financial Crises, International Money Regulation, Global Crises, Great Depression, 2008 Crisis

Jel Classification: G01,E32,F02,E42

\section{Giriş}

19. yy. Sanayi Devrimi sonrasında küresel ticaret ve finans ağları birbirleri ile hızl bir entegrasyon sürecine girmiş ve kapitalist evrimi şekillendirmiştir. Geride bıraktığımız iki asırlık süreç içinde kapitalist evrimin şekillenmesinde yaşanan finansal krizlerin kapitalizme olan olumlu ve olumsuz katkıları taban tabana zıt iki ayrı görüş birliğini hep karşı karşıya getirmiştir. Bir görüş yaşanan finansal krizlerin kapitalizmi daha iyi anlayabileceğimiz bir kıvama getirerek en iyi performansın sağlanacağını iddia ederken karşı görüş ise her yaşanan finansal krizin kapitalizmi gittikçe zayıflatarak çöküşün kaçınılmaz olacağını vurgulamaktadır. Enteresan olan ise bu görüş birliklerine ait beyanatların krizlerin başlangıç dönemleri ile ortaya çıkması ve kriz sonucu oluşan makro ekonomik büyüklüklerdeki hasarların zayıflama sürecine kadar azalarak devam etmesidir. Bu çalışmanın amacı; geçmişten gelen finansal krizlerin nedenlerine odaklanılarak, bugün ve sonrası için olası finansal krizlere karşı elde edeceğimiz derslerin ne olabileceği konusuna işık tutabilmektedir.

Çalışmanın ilk bölümü ekonomik krizin tanımı ve türlerinin kısaca açıklanmasıyla başlamaktadır. Bölüm içinde Sanayi Devrimi ile beraber ticaret ağlarının yayılması sonucu 18. yy. içinde finansal panikler olarak ortaya çıkan 
ve krizler olarak devam eden ekonomik krizler 1929 Büyük Depresyon'a kadar incelenmiştir. İncelenen dönem içinde yer alan finansal krizler 1929 Büyük Depresyon'a göre dar bir yayılım ve etki alanı yarattıklarından tek bir bölüm içinde açılklanmıştır.

İkinci bölüm; tamamen 1929 Büyük Depresyon üzerine odaklanmıştır. 1929 Büyük Depresyon küresel ekonomide kendisinden sonra oluşmuş finansal krizler için karşılaştırma yapılabilecek nitelikte geniş yayılım ve etki alanı yaratmış uzun vadeli bir finansal kriz olduğundan tek başına incelenmiştir.

Üçüncü bölümde önce; Büyük Depresyon'un Avrupa Kıtası üzerindeki etkileri araştırılmıștır. Dönemin bankacılık açısından kuvvetli para kurumlarına sahip Avusturya ve sanayi açısından lider konumdaki Almanya örnekleri seçilmiştir. Bölüm Büyük Depresyon'un nedenleri üzerine uluslararası literatürde kabul görmüş teorisyen görüşleri ile sonlanmaktadır.

Son bölümde ise; 2007-08 Krizi küresel ekonomide 1929 Büyük Depresyon gibi uzun vadeli ve geniş alan üzerinde etkiler yarattığı için Büyük Depresyon'la bir karşılaştırma niteliğinde kısıtlı teknik detay ve görüş içeren nitelikte incelenmiştir. Amaç geçmişten günümüze finansal krizlerin mihenk taşı niteliğinde görülen 1929 Büyük Depresyon ve 2007-08 Küresel Finans krizi arasında oluştukları dönem koşullarının birebir aynı olmamasına rağmen küresel para ve finans sistemi düzenlenmesinde gözden kaçan eksiklikleri tespit etmektir. Aynı zamanda geçmiş finansal krizlerden elde edilen tecrübelerin sistem eksikliklerinin giderilmesinde ne kadar faydalı olabileceğine dair fikir üretmektir.

\section{EKONOMIK KRIZ VE BÜYÜK DEPRESYONA KADAR YAŞANAN KRİZLER}

Kriz tanımı ekonomi alanından önce daha çok tıp alanında kullanılmıș ve birden beliren bir hastalık sürecinin başlangıcı olarak ve ya hastalık durumunun tedavisi zor bir döneme girdiğinin ifadesi olarak kullanılmıștır. ${ }^{1}$ Sosyal bilimler içinde ise daha çok 'buhran' ve ya 'bunalım' olarak kullanılmış, günlük dilde ise ekonomik, mali, siyasi, hükümet krizleri şeklinde kavramlarla kullanılmaktadır. $^{2}$ Ekonomi alanında kriz denildiği zaman ne şekilde tanımlanması gerektiği konusunda farklı açlklamalar ve görüşler ortaya çıkmaktadır.

${ }^{1}$ Coşkun Can Aktan ve Hüseyin Şen, Globalleşme, Ekonomik Kriz ve Türkiye, TOSYÖV Yayınları, 1999, s. 22.

2 Z. Dina Çakmur Yıldırtan, Finansal Krizler-Erken Uyarı Sistemleri, Nobel Dağıtım Yayınları, 2006, s. 39, 
Sayfa/Page | 80

İGÜ Sos. Bil. Derg.,

4 (1), 2017,

ss. 77-127.

Genel olarak ekonominin genleşme döneminde aşırı yükselen fiyatlar, krediler, üretim ve varlık değerlerinin şiddetli bir çöküş sürecine girerek bir noktada hareketsiz kalması krizlerin karakteristik özelliğini oluşturmaktadır. Ekonominin en uç düşük üretim seviyesinde takılı kalması, büyüyen likiditenin son bulması, zayıf firmaların piyasadan elenmesi ve ekonomik büyümenin iyimserlik sürecindeki bütün kuralsızlıkların sürdürülemez olduğunun anlaşılmasıyla piyasaların tekrar nefes almaya başlamak için piyasanın temizlenme sürecine girmesi kriz algısının temelini oluşturmaktadır. ${ }^{3}$ Kimi görüş yüksek enflasyonlu bir süreci kimisi ekonomik durgunluk ile ortaya çıkan deflasyonist bir süreci ekonomik kriz olarak betimlerken işin içine finansal ya da reel sektör krizleri tanımları girince ekonomik kriz tanımının net açıklanması daha kafa karıştırıcı bir hal almaktadır. Bütün bu ekonomik kriz tanımlama farklılıklarına rağmen genel olarak tüketici taleplerindeki azalmaya iştirak eden ulusal çıktı değerlerinin azalmaya başlaması, yüksek oranlı işsizlik ve buradan kaynaklanan ortalama yaşam standartlarının düşmesi konjonktürel dalgalanmaların içindeki ekonomik krizlerin en belirgin özelliği olmuştur. Nobel ödüllü iktisatçı Paul Samuelson'un 'Küresel finansal kriz hakkında bildiğimiz şey, pek fazla bir şey bilmediğimizdir' ifadesi ekonomik krizler hakkındaki bulgu ve çıkarsamaların hep bulanık kalacağının da bir göstergesi olacaktır. ${ }^{4}$ Kriz kelimesinin ekonomi alanında kullanılmaya başlanması ise genel olarak 19. yy. sürecine denk gelir. $\mathrm{Bu}$ süreç küresel ticaret ağlarının önem kazandığı ve uluslararası ticaret ve finans ağlarının önemli bir hızla kurulduğu bir dönemdir. Ekonomik krizler tarihsel süreç içinde kendilerini daha çok ticari sistemdeki çöküntüler olarak göstermişlerdir. Krizler şiddetli gelir dalgalanmalarıyla beraber arkalarından çöküntü sürecine girmiş endüstri grupları, iflas sürecine girmiş sermaye ve yoksullaşmış emek gücü bırakarak ağır hasar vermiş̧lerdir. ${ }^{5}$

Son iki yüz yıl içinde krizlerin örneklenmesinde farklı oluşum nedenlerinden ötürü çok sayıda ekonomik ve finans kriz türleri sınıflandırılmıștır. En fazla örneklendirmeye sahip olanlar ise para krizleri, bankacılık krizleri, dış borç krizleri ve finansal krizlerdir. Para krizi herhangi bir spekülatif etki sonrasında ülke parasının değer kaybetmeye başlamasıyla ortaya çıkabilir. Döviz kurlarındaki beklenmeyen yüksek oranlı hareketler ve sermaye hesabındaki ani yön değiştirmeleri de para krizinin en önemli göstergeleri olarak görülür. Bankacılık krizlerinde ise öz sermaye değerlerinin çok üstünde kredi faaliyetlerini sürdüren bankaların iflasları veya mevduat sahiplerinin güven eksikliğinden kaynaklanan yüklü mevduat geri çekişleri ilk

3 Wilhelm Röpke, Crises \& Cycles, The Ludwig von Mises Institute Publishing, 2007, s.

28.

${ }^{4}$ Mahfi Eğilmez, Küresel Finans Krizi-Piyasa Krizinin Eleștirisi, Remzi Kitabevi,

3.Baskl, 2009, s. 48.

${ }^{5}$ Edward David Jones, Economic Crises, General Books LLC, 2009, s. 1. 
dikkat çeken faktörlerdir. Finansal krizlerde finansal sistemin varlık değerlendirmesi, kredi tahsisi ve ödemeler gibi önemli işlevler kesintiye uğrar. Ayrıca likidite problemi de önem arz ederken spekülatif hareketlerin yarattığı baloncukların patlaması da dikkat çeken bir başka unsurdur. Dış borç krizleri ise, bir ülkenin kamu ya da özel kesimden kaynaklanan borç ödemelerini gerçekleştiremeyerek moratoryumun ilan edilmesi ile oluşur. ${ }^{6}$

Finansal çöküşlerin 19. yy.'ın ikinci yarısından itibaren Avrupa sınırları içinde yayılan Sanayi Devrimi ile başlaması ve ticari bağlantıların yayıldığı diğer kıta ülkelerine sıçraması tesadüfi olarak algılanmamalıdır. Tarih içinde bilinen ilk finansal panik 1792 yılında Amerika Sermaye Piyasasında gerçekleşmiştir. İki hafta içinde hisse senedi değerlerinin yaklaşık \%25 gibi değer yitirmesiyle sonuçlanan 1792 Paniği ilk sermaye piyasası iflasına örnek gösterilmektedir. Dönemin Hazine Sekreterliğine atanan Alexander Hamilton'un ustaca müdahalesi sonucu, 1792 Finansal Paniği yeni ulusal düzene girmiş Amerika'da ciddi ekonomik hasar yaratan bir krize dönmüştür. 1792 Finansal Paniği sırasında hisse senedi fiyatlarının aşırı şişmesi ve bu şişmenin finansal bir çöküş yaratmadan hangi yetkili kurum tarafından nasıl kontrol altına alınabileceği sorusu önem kazanmıştır. Hazine Yönetimi Sekreteri Hamilton piyasa aktörlerini ikna yöntemi ile ulusal bankaların kredi yaratabilmelerini kademeli sınırlandırmaya başlatması paniğin atlatılmasında olumlu sonuç vermiştir. Bu tür bir uygulama Avrupa ekonomisinde ortalama seksen yıl sonra Merkez Bankacılı̆̆ı kriz yönetimi üzerine dayalı "Bagehot" kuralların yazılmasına da olanak vermiştir. ${ }^{7}$

Amerika Sermaye Piyasasının kalbi Wall Street odaklı ikinci ulusal bankalar paniği 1826 yılında yaşanmıştır. 1826 yılında yaşanan bankalar paniğinin gerisinde 1824-1825 yılları arası New York bankalarının spekülatif hareketleri sonucu geniş kitlelere yoğun kredi satışı yaparak parasal genişlemeye katkıda bulunmaları yatmaktadır. 18. yüzyılın ilk dönemlerinde bankacılık sektörünün sanayi sektörüne göre kazançlı olması dönemin bankalarının sayı olarak artmasına ve kredi toplama ve satış tekniklerinde de denetleyici bir kurallar zincirine bağlı olmadan yenilikler yapmalarına neden olmuştur. Bankacılık sektörünün dışındaki sigorta şirketleri ise hamiline posta çeki yapısına benzer ileri bir vadede ödenmek üzere borç senetleri tanzim etmiştir. New York da faaliyet gösteren Hayat ve Yangın Sigorta Şirketi (The Life and Fire Insurance Company) bu tür bir hamiline posta çeki karşılığında 1824-1825 yılları arası toplam değeri bir milyon dolarlık hamiline posta çeki karşılığı kredi toplayabilmiştir. 1825 yılının sonlarına doğru sigorta

${ }^{6}$ Mustafa Özer, Finansal Krizler, Piyasa Başarısızlıkları ve Finansal İstikrarı sağlamaya Yönelik Politikalar, Anadolu Üniversitesi Yayınları, 1996, ss. 29-38.

${ }^{7}$ Richard Sylla, R. Wright, D.Cowen, "Alexander Hamilton, Central Banker: Crisis Management during the U.S. Financial Panic of 1792", Business History Review, 83 (Spring 2009), s. 61, 64-65.

Sayfa/Page | 81

IGU J. Soc. Sci., 4 (1), 2017, pp. 77-127. 
Sayfa/Page | 82

İGÜ Sos. Bil. Derg.,

4 (1), 2017, ss. 77-127.

sektörünün de darboğaza girmesi ve Hayat ve Yangın Sigorta Şirketi'nin sermaye piyasasındaki yer alan hisse senetlerinin değer yitirmeye başlaması sonucu ellerinde bu şirkete ait hamiline senetleri tutanlar senet değerlerinin paraya çevrilmesi için sigorta şirketine hücum etmişlerdir. Ancak elinde ödeme yapması için yeterli nakit varlığı olmayan sigorta şirketi iflas etmiştir. $\mathrm{Bu}$ iflas New York Sermaye Piyasası kanalı ile birbirine bağlı sigorta ve bankacılık kurumlarını zincirleme bir reaksiyon halinde etkilemiş, sonuç olarak bir dizi banka ve sigorta şirketi iflas etmiştir. Bu olay kredi ve parasal genişleme süreçlerini ihtiyatlı takip edecek kurumların ve düzenleyici kuralların gerekliliğini ortaya çıkarmıştır. ${ }^{8}$

1800'lü yıllar gerek İngiltere gerekse Amerika kıtasında karşılıklı ticaret ve bankacılık sektörünün artan ticaret ilişkileri ile birlikte büyüdüğü bir dönem olmuştur. Londra tabanlı bankerlerinin çoğunun Amerikan kıtasına yönelik yatırım girişimleri ile New Orleans gibi güney Amerika bölgeleri nüfus, ticaret ve finans alanında hızlı bir büyüme sürecine girmişlerdir. Bu dönem içinde ticareti ve finans ödeme sistemini kolaylaştırmak için kullanılan sterlin cinsi keşide edilmiş ödeme senetleri (foreign bill of exchange) Amerikan finans sahası içinde bir ödeme aracı olarak kullanımı arttıkça yüzyılın ilk önemli sayılabilecek finans çarpıklığı olan 1837 Paniği yaşanmıştır. İlgili dönem içinde finansal saha kontrolleri ve regülasyonlarının hiç olmayışı nedeniyle ödeme sistemlerinin aniden durması New Orleans- Londra- New York üçgenindeki panik ve kriz yayılımlarının ilk önemli örneklerinden biri sayılabilir. 1837 Paniği bu açıdan bir görüş olarak bankacılı̆̆ın ve finansal faaliyetlerin gün geçtikçe kumar olayları haline dönmesinin dikkate alınması gereken bir evresi olarak düşünülmektedir. ${ }^{9}$

18. yüzyıl başlarından itibaren yaşanan finansal panikler ve çöküşler, finans şirketlerinin iflasları dönemin bazı ulusal para otoritelerinin kurumsal düzenlemeleri almalarına neden olmuştur. Bilinen en somut örnek İngiliz Merkez Bankası'nın uygulamalarıdır. Finans alanında sıkıntıda olan mali kurumlara yetkili para otoritesi olan Merkez Bankasının teminatlar karşılığında kredi verilmesinin avantajını ortaya koyan Bagehot kurallarının yazılmasından önce 19. yüzyıl içinde banka krizleri ile oldukça mücadele etmeye çalışan İngiliz Merkez Bankası, 1844 yılında finans sahasının daha etkin kontrolü için yeni bir yasa oluşturmuştur. Bu yeni yasanın en önemli özelliği ulusal Merkez Bankasını iki ayrı üniteye ayırmış olmasıdır. İngiliz Merkez Bankası Banknot ve Bankacılık Departmanı olarak birbirinden bağımsız iki yarı üniteye bölünmüştür. Özellikle Banknot Departmanının

${ }^{8}$ Eric Hilt, "Rogue Finance: The Life and Fire Insurence Company and Panic of 1826", Business History Review, 83, (Spring 2009), ss. 87-100.

${ }^{9}$ Jessica M. Lepler, The Many Panics of 1837-People, Politics and the Creation of Transatlantic Financial Crisis, Cambridge University Press, 2013, ss. 20-42. 
banknot ihracında bazı yetkilerinin kısıtlanması para okullarının aşırı banknot ihracının önlenmesine yönelik hedeflerine sınırlı șekilde uymaktaydı. Ne var ki bu uygulama İngiltere'de yaşanacak finansal krizlerde Ulusal Merkez Bankası'nın finansal sistemi rezervleri ile stabilize etmesinde gereken etkiyi göstermemiştir. Zira ulusal İngiliz Merkez Bankası'nın resmi olarak bu rezervleri kullanabilme yetkisinin olmaması kriz dönemlerinin engellenebilmesini zorlaştırmıştır. ${ }^{10}$

18. ve 19 yy. finansal panik ve kriz analizlerinin çıkış noktası ilgili dönem gözlemcileri tarafından ısrarla sadece ulusal sınırlar içindeki içsel faktörlerle açıklanmıştır. Uluslararası para sisteminde çift metal para düzeninden gümüş değerinin çıkartılarak altına dayalı bir para düzenine geçişin Londra Para Piyasası'ndaki yarattığı etki diğer Avrupa Para Piyasası noktalarında olumsuz etki yapmasına rağmen ilgili dönem içinde hep ulus içi faktörler ile açıklanmaya çalışılmıştır. 1890 yılında kuvvetli bir İngiliz ticaret bankası olan Baring'in iflasının gerekçeleri Arjantin'deki dış borç krizi ile başlayıp New York sınırlarına ulaşmıştır. Fakat dönemin gözlemcileri ulus içi faktörlere dayalı gerekçe açıklama yoluna gitmişlerdir.11 19. yy. ikinci yarısından itibaren İngiliz Bankası Arjantin, Uruguay gibi Latin Amerikan ülkelerine yatırımlarının finansmanı için yüklü kredi satışı yapmaya başlamıştır. Bu ülkelerdeki yatırımların hızlı bir şekilde dış kredileri ödeyecek nitelikte geri dönmemesi sonucu Baring Bankası 200 Milyon Sterlin değerindeki borç yükü ile iflas etmiştir. Bankanın iflasıyla ile ticari ilişkisi olan New York Bankaları'nda da panikler ve bir dizi iflaslar yaşanmıştır. ${ }^{12}$ Dikkat edilirse endüstriyel ve ticari ağların yoğunlaşmasıyla beraber Avrupa ve Amerika kıtasında 18. yüzyılın başından itibaren finansal kırılganlıklar artmıştır. Bu dönem yoğun kırılganlıklarıyla beraber tahmin edilebilmesi zor depresyon ve kriz süreçlerini de başlatmıştır.

19. yy. içinde demiryolları ve kıtalar arası deniz yolları ulaşım ağlarının artarak ticaret yollarını genişletmesi küresel pazarı da büyütmüştür. Büyüyen küresel pazar neticesinde Kita Avrupasındaki koruyucu gümrük duvarları Almanya ve İskandinav ülkelerini yeni ekonomik güçler olarak küresel sistemin içine sokmuştur. Yeni ekonomik güçlerin oluşumu ticaret ve finans alanlarını yöneten Merkez Bankaları gibi yeni kurumsal aktörlerin yükümlülüklerini de artırmıştır. İlgili yüzyıl içinde bu yeni kurumsal aktörlerin uluslararası sermaye piyasası hareketlerini yönetebileceği

\footnotetext{
10 Kenneth Kuttner, "Victorian Financal Crises and Their Implications for the Future", Business Economics, 2010, Vol: 45 no: 2, ss. 102-103.

11 Charles Poor Kindleberger, Historical Economics- Art or Science, Univercity of California Press-Berkeley and Los Angeles, 1990, s. 310.

12 Sinan Sönmez, "Kalkınmanın Finansmanı, Emperyalizm ve Finansal Serbestlik Üçgeninde Dış Borçlanma”, Ekonomik Yaklaşım, Cilt: 21, Sayı 75, s. 126.
}

Sayfa/Page | 83 IGU J. Soc. Sci., 4 (1), 2017, pp. 77-127. 
Sayfa/Page | 84

İGÜ Sos. Bil. Derg.,

4 (1), 2017,

ss. 77-127.

umulmuştur. ${ }^{13}$ Krizlerin oluşumunda ticari faaliyetleri yoğunlaşan iki kita ekonomisi arasında farklılıkların oluşu dönem krizlerin oluşum gerekçelerini de çeşitlendirmiştir. Amerika'da daha az bir sermaye değeri varken Avrupa kıtasında fazla sermaye ve yüksek mobilete, fiyatların etkilenmesi ve iktisadi akımların çoğalmasına oldukça katkıda bulunmuştur. Amerika'da zayıf sermaye yapısı faiz oranları üzerinde büyük artışlara neden olurken abartılı bir girişimcilik akımı büyümeyi hızlandırmıştır. Kaliforniya da altın madenlerinin bulunması ve göç akımlarının hızlanması gibi faktörler yüzünden 19. yy.'a kadar Amerika kıtasında yaşanan krizlerin gerekçelerini diğer yeni sanayi ülkelerindeki krizlere göre farklılaşmıştır. ${ }^{14}$

1857 krizi ise modern kapitalist tarihin ilk kıtalar arası finans krizi olarak anılır. Daha önceki bazı kriz ve paniklerdeki gibi İngiltere'nin ticaret yaptığı ülkeler ile arasında oluşan bir gelir veya ticaret hacmi dalgalanması sonucu oluşmamıştır. Bunun dışında 1857 Krizi'nin çıkması için savaş, tarım veya emtia piyasasındaki aksaklıklar gibi sıklıkla rastlanan nedenlerden hiç biri mevcut değildi. Bu yüzden 1857 yılında Amerika'da yaşanan finansal kriz ve depresyon süreci dönemin tetikte bekleyen finansman yatırımclarına bile sürpriz niteliğinde gerçekleşmiş ve 12 Ekim 1857'de 63 ticari bankadan 62 tanesi ödeme yapmayı durdurmuştur. Bir ay içinde İngiltere ve Avrupa kıtası içindeki birçok ulusal banka ve borsa kurumları da ödemelerini durdurarak depresyon sürecini kendi topraklarına taşımışlardır.15 1857 Krizi daha önceki finansal bozukluklarla karşılaştırıldığında ise ilk dikkati çeken ticaret bonolarında alışılmamış bir durgunluğun sonrasında yaşanmış olmasıdır. 1857 Kriz analizinde dönemin ekonomistleri ve bankerleri farklı açllardan görüş bildirmelerine rağmen dikkate ilk çeken özellik krizin ticari bono ve senet işlemlerindeki alışılmamış bir durgunluk sonrası patlak vermiş olmasıdır. Bazı bankerler New York City bankasının on yıllık periyotlar içinde ödünç işlemlerini nedensiz daraltarak finans sahası üzerinde stres biriktirdiğini iddia etmişlerdir. Bu süreçte diğer New York Bankaları da mevduatlarını geri çekerek finans alanındaki stresi artırmışlardır. Dönem içinde banka ve firmaların aşırı spekülasyonel davranışları da eleştirilen bir unsur olmuştur. 1857 yılının ikinci yarısından itibaren İngiltere'den Amerika'ya yönelik sermaye akımlarının zayıflamasının sonucu olarak Amerikan varlık fiyatlarının inişe geçtiğini ve bunun da önce Ohia Hayat Sigortası ve Bankasına (Ohia Life Insurance and Trust) sonra diğer bankalara yansıdığı da iddia edilen görüşlerden bir tanesidir. 1857 Finansal Krizinde Doğu Eyaletlerindeki toprak spekülasyonun azalmasıyla karlılık oranları

${ }^{13}$ Harold James, "Globalizition and Great Depressions", Foregin Policy Research Instute, Winter 2002, www.elsevier.com, ss. 128-129.

${ }^{14}$ Theodore E. Burton, "Financial Crises", BiblioLife, LLC Publishing, Orginal Copyright 1902 by D. Appleton and Company, www.books.google.com, ss. 282-283.

${ }^{15}$ J.R.T. Hughes, "The Commercial Crisis of 1857", Oxford Economic Papers, New

Series, Vol: 8, No: 2, June 1956, s. 194. 
düşmüş ve demiryolu varlık yatırımları hızla değer kaybetmiştir. Bu varlıkları elinde tutan bir dizi banka ve para kurumları iflas etmiştir. 1857 Finansal Kriz Amerika ve Avrupa Kıtasında birçok ulusal bankanın domino etkisi ile kapanmasına neden olmuştur. ${ }^{16}$

Dünya ekonomi tarihi içinde oluşan kriz ve paniklerin çoğunun gerisinde finansal veya ticari çarpıklıklar olmasına rağmen finansal çarpıklıkların oluşumunda çoğu kez savaşlar da aktif rol oynamışlardır. 1856 yılı Kırım Savaşı sonrası Avrupa ve Amerika kıtası arasında finansal sistem çarpıklığının yayılması hızlanmıştır. Savaş sonrası dönemde Amerikan buğdayına yönelik talebin ani azalması Amerikan buğday fiyatlarının çakılmasıyla sonuçlanmıştır. Bu durumsa Avrupa'daki buğday üreticilerini likidite sıkışıklığına sokmuştur. Avrupa bankalarının Amerikan bankalarındaki mevduatlarını geri çekmesiyle Amerikan bankalarının rezervleri erimiş ve kredi verme güçleri azalmıştır. Avrupa ve Amerika kıtası arasındaki ekonomik aktivite ve finans işlemlerinin zayıflaması beraberinde Amerikan demiryolları hisse senetlerinde spekülatif dalgalanmalar göstermiştir. $\mathrm{Bu}$ zincirleme reaksiyonlar Amerika'da Ohio Hayat Sigortası ve Bankasının psikolojik bir şoktan ötürü iflas etmesine neden olacak bir finansal krizin koşullarını beraberinde getirmiştir. ${ }^{17}$ Yukarıdaki örnek krizlerin oluşumunda ekonomi tabanlı faktörlerin dışında kalan siyasi ve politik etmenlerin de dikkate alınmasını gerektirmektedir.

19. Yüzyılın ilk yarısındaki finansal krizler uluslararası ticaretle bağlantıları olan kısa vadeli krizlerdir. Buna karşın yüzyılın ikinci yarısındaki krizler ise geniş yayımlı ve uzun vadeli krizlerdir. 1873 krizi bu tür uzun vadeli ve kıtalararası etki yaratan ilk finansal krizdir. 1873 yılında Viyana'daki bankalar paniği kısa sürede diğer Avrupa finans şehirlerini de etkilemiş ve Amerika'nın büyüme motoru olan demiryolu sektörüne yatırım yapan ulusal sermaye piyasasında çalkantılar başlatmıştır. Amerikan ulusal sermaye piyasasındaki değer kayıpları birçok ulusal demiryolu projesinin iptaline neden olurken yaklaşı 5 yıllık bir durgunluk sürecini başlatmıştır. Bu kriz aynı zamanda sanayi ülkeleri dışında yer alan Osmanlı İmparatorluğu ve bir dizi Latin Amerika devletini de borç krizine sokmuştur. ${ }^{18} 1870$ yılı sonrası yaşanan krizlerin daha sert ve geniş yayımlı olmasındaki gerekçeler dönemin kompleksleșen para ve banka sisteminin ve her iki kıtada sayıları artan entegre olmuş para aktörlerinin varlığı altında incelenmelidir. Bu yüzyıl içinde dünya finansmanı Londra ve Paris Para Piyasası hâkimiyeti altında idi. Bunun

\footnotetext{
16 Charles W. Calomiris \& Larry Schweikart, "The Panic of 1857: Origins, Transmission, and Containment", The Journal of Economic History, Vol: 51, no: 4, 1991, ss. 808-809.

17 Larry Allen, The Global Financial System: 1750-2000, Reaktion Books Publishing, 2001, s. 215

${ }^{18}$ Carlos Marichal, "World Financial Crises. Lessons of the Past", Finance \& The Common Good/BIEN Commun, Volume II-III, 2009, ss. 37-38.
}

Sayfa/Page | 85 IGU J. Soc. Sci., 4 (1), 2017, pp. 77-127. 
Sayfa/Page | 86

İGÜ Sos. Bil. Derg.,

4 (1), 2017,

ss. 77-127.

dışında finans merkezleri ise Londra ve Paris Para Piyasalarının uyduları konumundaydı. Bu iki büyük finans merkezindeki dalgalanmalar kolayca diğer finans merkezlerini etkileyebiliyordu. 1873 Krizinde Avrupa Bankacllık ve Finans Sistemindeki bir bozulma yatırım ilişkileri içinde bulunulan Amerikan Demiryolları Sektörü finansörlerini zayıflatarak her iki kıtada domino etkisiyle iflaslara neden olmuştur. 1873 yılında yaşanan Finansal Kriz bu tür paniklerin kıtalar arası küresel finans piyasasının asimetrik enformasyon eksikliğinden dolayı ne kadar kırılgan olabileceğini göstermiștir. ${ }^{19}$ Amerikan Demiryolları Sistemindeki aksaklık nasıl Avrupa Yatırım Piyasası aktörlerini etkileyebilmiş ise Avrupa İmar Sistemindeki iflaslar da aynı şekilde Amerika Yatırım Piyasası aktörlerini etkilemiştir. Finans sistemi içindeki bu kırılganlık birbirleriyle sıkı ticaret ve finans bağları olan iki kıta ekonomisini de sıkıntıya sokarak 1873 krizinin boyutunu kıtalar arası genişletmiștir.

19. Yüzyılın son 20 yılı Avrupa'nın Amerikan kapitalizminin yakaladığı yüksek hıza erişmekle geçmiştir. Dönem Avrupa büyük şehirlerinin büyük imar projelerine imza attığı bir dönemdir ve Paris, Berlin, Viyana gibi büyük Avrupa şehirlerinde ipotekli krediler kullanılarak büyük bir imar hamlesi oluşmuştur. Amerika ise tarım ve hayvancllık sektörü yüksek verimli üretim sergilediğinden dolayı Avrupa tarım sektörü rekabet gücü azaltmıştır. Rekabet gücü zayıflayan Avrupa'da ulusal gelirlerin düşmesine bağlı olarak kredi geri ödeme gücü zayıflamıştır. Kredi ödeme aksamalarının artmasıyla beraber problem Avrupa Emlak piyasasına süratle yansımıştır. İngiliz Bankalarının da kredi musluklarını Avrupa için kapatması sonucu 1873 Avrupa ekonomisindeki kriz kaçınılmaz bir şekilde demiryolları şirketlerine yatırım yapılan Amerikan ekonomisine de sıçramıştır. 1873 Krizi küresel finans, ticaret ve sermaye düzenin kıtalar arası entegrasyonunda gelecekte finansal kırılganlıkların boyutunun genişleyeceğinin sinyalini netleștirmiştir. ${ }^{20}$

1873 krizi arkasından 1929 Büyük Krize kadar dünya ekonomisi 1884, 1890,1896 ve 1907 yıllarında risk içeren farklı şiddetlerde ağırlıklı banka iflasları nedenli bir sürü finansal panik ve krizler geçirmiştir. 1873 sonrası 1890 Krizi de yine kendisinden önceki krizler gibi bir dizi olaylar serisi sonucunda ortaya çıkmıștır. Alman yatırımcıların Arjantin'deki 3,5 Milyon Sterlin değerindeki büyük su artıma projesine verdikleri kredi desteğini geri çekmeleri neticesinde hem Arjantin Hükümeti hem de Arjantin Hükümeti'ne destek sağlayan Baring Brother Bankası zor durumda kalmıștır. Bu olayda İngiliz Merkez Bankası, Baring Brothers yetkililerini Arjantin'e yönelik kredi kaynaklarını kısıtlama konusunda uyarmış ama banka yetkililerin bu uyarıyı

${ }^{19}$ Frederic S. Mishkin, "Asymmetric Information and Financial Crisis. A Historical Perspective" in Financial Markets and Financial Crises, Edited by R. Glenn Hubbard, NBER Publishing, 1991, ss. 81-82.

${ }^{20}$ Hayri Kozanoğlu, Küresel Krizin Anatomisi, Agora Kitaplığı, 2009, ss. 148-149. 
dikkate almamaları bankanın iflası ile sonuçlanmıştır. Akabinde İngiliz Merkez Bankası aynı bugün IMF'nin borç yükünden dolayı iflasa gidebilecek ülkeler için yaptığı gibi, ticari bankaları birbirlerine bir garanti sistemi altında bağlayacak bir organizasyon yapılandırmasına girmiştir. 19.yüzyıl sonlarında İngiliz Merkez Bankasının yapmış olduğu faaliyet aslen günümüzde 1998 Asya krizi sürecinde Amerikan Merkez Bankası'nın (FED) hegemonik bir iktisadi güç niteliğinde yapmış olduğu fonksiyonel görevden aslen farklı olmamıştır. ${ }^{21}$

Finansal panikler ve mali çöküşler özellikle 1929 Büyük Depresyon'a kadar Amerikan ekonomisini yalnız bırakmamıştır. Bunda dönemin Amerikan ekonomisinin genç ve büyüyen bir yapı sergilemesinin payı oldukça büyüktür. 1890 ortalarından 1906 sonuna kadar yıllık \%7,3 gibi büyüme rakamı sergileyen Amerikan ekonomisi büyük miktarda yatırımcı ve sanayici sayısına kavuşmuştur. Bu durum ulusal sermaye piyasalarında daha fazla sermayedar ve dolayısıyla spekülatörün hareket etmesine de neden olmuştur.19. yy. içinde 1800'ün üzerinde aracı ve finansal şirket kurulmuştur. Krizler tarihi içinde önemli bir tutan 1907 Paniği ve yaşanan finansal kriz, endüstrileşme sürecine eşlik eden genleşmiş bir sermaye piyasası sürecinin aslında ne kadar tehlike yaratabilecek bir ortamı doğal olarak oluşturabileceğini de bu açıdan göstermiştir. 1906 yılında öz sermayesine bağlı olarak çalışan piyasa halen cazibesini sürdürmekte iken hisse senedi ve finansal sektör piyasası reel sektörü gölgelemeye başlamıştır. 1906 yılının başından sonuna kadar düzensiz ama kuvvetli para talebi Wall Street ve diğer finansal işletmeler için dengesiz parasal koşullar yaratmıştır. Hisse senedi fiyatları artarken tahvil ve bono fiyatlarının azalması parasal sektör içinde keskin bir ayrışmaya neden olmuştur. Hisse senedi piyasasındaki bu fiyat hareketleri Amerikan ekonomisinin hızlı büyümesinden kaynaklanan kredi talebi artışından ve 1906 yılının yüksek tarım getirisinden kaynaklanmıștır.22

Hisse senetleri piyasasındaki şişme hareketler 1907 yılında Knickbocker Bankerlik Şirketi'ni zor durumda bırakmış ve şirket Avrupa Bankalarına yönelik ödemelerini durdurmak zorunda kalmıştır. Bu yüzden 1907 Krizi literatürde Knickboxer krizi olarak da anılmaktadır. Bankerlik Şirketinin ödemelerini durdurması gecelik faiz oranlarını \%125'in üzerine çlkartmış ve kredi piyasası içindeki bütün aktörler arasında panik hareketi baş göstermiştir. "Knickbocker Krizi" güven mekanizmasının finans ve kredi piyasasında ne kadar önemli olduğunu ispatlayan krizlerden bir tanesi olmuştur. ${ }^{23} 1907$ krizinin güven bunalımları dışında verdiği diğer mesaj da ulusal ekonomilerin büyüme sürecine girmeleri sonrası finans ve para

${ }^{21}$ Meghnad Desai, Financial Crises and Global Governance, Routledge Publishing, 2004, ss. $11-12$.

22 Robert F. Brunner \& Sean D. Carr, The Panic of 1907-Lessons Learned from the Market's Perfect Storm, Published by John Wiley \& Sons, New Jersey, 2007, ss. 7-17. ${ }^{23}$ Wilhelm Röpke, a.g.m., s. 36.

Sayfa/Page | 87

IGU J. Soc. Sci., 4 (1), 2017, pp. 77-127. 
Sayfa/Page | 88

İGÜ Sos. Bil. Derg.,

4 (1), 2017, ss. 77-127.

piyasalarındaki gelişmelerin hassasiyetle takip edilme zorunluluğunu ortaya çıkarmıştır. Gerçekten de 1907 yılına doğru büyük bir konjonktürel genişleme sürecine giren Amerikan ekonomisi aynı gelişimi ulusal para ve finans sektöründeki gözetim ve denetleme aşamasında gösterememiştir. 1907 yazında ulusal para piyasasının daralması ki bu dönem Amerika'daki emtia ticaret hacminin hızlı iniş sürecine girdiği zamandır; sert finansal sıkışıklıklara neden olarak aracı bir kurumun iflas etmesi ve ödemelerini durdurmasıyla finans ağı içinde yer alan para kurumlarını panik havasına sokmuştur. Hızlı büyüme sürecine giren Amerikan ekonomisi 1907 krizi sonrası sert bir yavaşlama dönemine girmiş ama buna rağmen kısa süreli bir durgunluk ve gecikmeli tepki hareketlerinden kurtulamamıștır. $\mathrm{Bu}$ panik bankacılık reformları üzerindeki tartışmaları alevlendirirken 1913 ve 1914 yılında oluşacak Federal Rezerv Sisteminin yaratılmasına öncülük edecek Birleşik Devletler Ulusal Para Komisyonu'nun kurulmasına gerekçe doğurmuştur. ${ }^{24}$

1907 Krizi dönemin büyük banka sahiplerinden JP Morgan'ın bankalarından birisinin diğer bankaların mevduat geri ödemelerini garanti göstermesi ve finans piyasası içindeki diğer para kurumlarına güven telkini sağlaması ile son bulmuştur. 1907 Krizi diğer bankacılık krizleri ile karşılaştırıldığında oldukça kısa sürede sona ermiştir. Aynı zamanda 1908 yılında Amerikan Kongresinde kabul edilen Aldrich-Vreeland Kanunu panik durumunda finans sektörüne acil para ve kredi temininin sağlanmasına olanak vermiştir. 1907 Krizi bu evrelerle beraber ulusal bir Merkez Bankasının kurulmasına yönelik bir seri yasal düzenlemelerin de hızlanmasına neden olmuştur. Bu yasal düzenlemelerin ilk örneği 13 Aralık 1913'te Amerika Başkanı Woodrow Wilson tarafından imzalanan Federal Rezerv Yasası'dır. Bu kriz Amerikan hükümetinin yetkili organları üzerinden ulusal borsa ve sermaye piyasası aktivitelerine daha fazla yoğunlaşmasına ve özellikle hisse senedi manipülasyonlarına karşı temkinli ve tepkili davranmasına da neden olmuştur. ${ }^{25}$

1907 Krizi'nde spekülatif davranışların hakim olduğu ahlaki finans geleneklerinin dışında bir finans yönetimi sergilenmiştir. Bankaları, sigorta ve endüstri şirketlerini finansa eden yatırımcların fonları hatalı yönetmeleri ve spekülatif amaçlar için serbestçe kullanmaları sonucu mevduat sahiplerinin paniklemesine ve kredi sisteminin çökmesine neden olmuştur. Bu Amerikan Borsa krizi artık Avrupalı ekonomistlerin de krizlere karşı daha duyarlı şekilde çalışmalarını bu alana doğru odaklanmalarıyla sonuçlanmıştır. Bunun en iyi bilinen örneği Knutt Wicksell'dir. Wicksell 1907 Mayıs'ında Oslo Üniversitesinde ekonomik dalgalanmalara dayalı "The Enigma of Business

${ }^{24}$ George Rich, The Cross of Cold-Money and the Canadian Business Cycle in 1867-1913, Carleton Univercity Press, 1988, s. 164.

${ }^{25}$ Rik W. Hafer \& Scott E. Hein, The Stock Market, Greenwood Press, 2007, s. 17. 
Cycles" isimli dersi vermeye başlamıştır. Bunu takip eden yıl içinde 1907 Krizinin parasal ve reel etkilerini analiz eden üç ayrı makale çıkartmıștır. Wicksell kriz analizlerinde banka ve finans sektörü için üç ayrı nitelik tanımını ortaya koymuştur. Bunlar borçların ödenebilme yeteneği, likitide ve esnekliktir. Ona göre bir banka ya da para kurumu reel varlık ihracını güven içinde mevduat sahiplerine sunabiliyorsa ve kendisine yönelik ödemeler herhangi bir olaydan ötürü aksasa bile reel varlıklarının değerini koruyabiliyorsa o zaman ödeyebilme yeteneğine sahiptir. Şayet banka günün birinde talep edilirse ödeme yapabilecek şekilde görevini yerine getirebiliyorsa o zaman likidite niteliğine de sahip olacaktır. Son olarak banka herhangi bir olay karşısında makul bütün kredi taleplerini kabul edilebilir faiz oranları bandajı içinde karşılayabiliyorsa o zaman esnek yapıya sahip olacaktır. Wicksell 1907 krizinin özünde Amerikan Finans kesiminde yer alan para kurumlarının yukarıda sayılan üç tanımlayıcı nitelik açısından zayıflıklarının olduğunu ileri sürmüştür. ${ }^{26}$

\section{1929 BÜYÜK DEPRESYON}

1907 krizi sonrasında gerek Amerikalı gerekse Avrupalı iktisatçılar tarafından ortaya çıkartılan bulgular krizleri önlemek için bir takım ulusal düzenlemelere gidilmesine olanak vermiş olmasına rağmen yaşanılan dönemin hâkim iktisadi düşünce yapısı ve birçok ülkeyi içine çekecek 1. Dünya Savaşının yaşanması nedeniyle, krizlerin etkin bir şekilde önüne geçebilecek iktisat politikaları oluşmasını engellemiştir. Savaş sonrası gelişmiş sanayi toplumları ve onlara eşlik eden yenidünya ülkeleri hızlı bir kalkınma ve büyüme sürecine girdiklerinden finansal kriz ve panikler ile ilgili endișeler, çözüm arayışları geçici olarak arka plana itilmişlerdir. Lakin bu arka plana itilmişlik küresel finans sistemine tam olarak eşlik edemeyecek olgunlaşmamış uluslararası bir para sisteminin sürmesine neden olmuştur. 1929 Büyük Buhran'a kadar para sistemleri çarpıklığı devam etmiş ve dünya ekonomisindeki en derin ve efsanevi kriz 'Kara Perşembe' olarak anılan 24 Ekim 1929 Perşembe günü New York Borsasında patlamıştır. Kriz dalga dalga yayılarak ilk hafta içinde sadece Amerika'da 4000 irili ufaklı bankanın iflasına ve büyük mali, servet kayıplarına neden olmuştur. Dünya ekonomisini ciddi sarsan 1929 Büyük Buhran'ın anlaşılması için dünya ekonomisi ve siyasi tarih gelişimine sonra da Amerikan ekonomisine ve Amerika'nın iç politika sürecine odaklanan on yıllık bir süreç de incelenmelidir.

Birinci Dünya Savaşı uluslararası ticaret ve finans düzeninde ciddi bozulmalara neden olmuştur. Savaş sırasında uluslararası sermaye akımlarının kesintiye uğraması, mal ve hizmet akımlarının kesilmesi ve altın

${ }^{26}$ Mauro Boianovsky, "Wicksell on the American Crisis 1907", Journal of History of Economic Thought, Vol: 33, 2, 2011, s. 1-6.

Sayfa/Page | 89

IGU J. Soc. Sci., 4 (1), 2017 , pp. 77-127. 
Sayfa/Page $\mid 90$

İGÜ Sos. Bil. Derg.,

4 (1), 2017,

ss. 77-127.

standardı sisteminin terk edilmesi birçok ülkede birbirleriyle uyuşmayan politikaların aktifleşmesine neden olmuştur. Savaşa katılan birçok ülkede devletin üretimdeki rolü artmaya başlamış, para ve maliye politikası disiplini gevşemiştir. Savaş aynı zamanda dönemin imparatorluk güçleri arasında bir yer değişime de neden olmuştur. Avrupa ülkeleri savaşın etkisi ile zayıflarken Amerika ve Japonya ekonomik güç olarak kuvvetlerini artırmışlardır. Uluslararası finans sisteminin aktörleri 1925-1928 yılları arasında altın para sistemin yeniden düzenlemek istemişlerdir. İngiliz Merkez Bankası Birinci Dünya Savaş'ından önceki pozisyonundaki gibi tek bir Dünya Merkez Bankası niteliğinde uluslararası para ve finans sistemini kontrol edebilecek gücünü kaybetmiştir. Fransa ve Amerika da düzenin yeni ve güçlü aktörleri olarak yerlerini sağlamlaştırmışlardır. Ne Fransa ne de Amerika eski uluslararası finans sisteminin kurallarına göre hareket etmiyor ve her iki ülke para politikalarını rahatlatacak altına dayalı sermaye akımlarını teşvik edecek şekilde davranmışlardır. Yeni sistemde daha büyük rezervlere ihtiyaç vardı fakat ödünç alan ve veren ülkeler arasındaki dengelerin değişimi sonucu uluslararası finans sisteminde da son ödünç veren merciin belirlenmesi zorlaşmıştı. Fransa ve Almanya savaş öncesi ödünç veren pozisyonunda iken ödünç alan konumuna düşmüşlerdi. İngiltere'nin ödünç verebilme kapasitesi azalırken Amerika ödünç alınabilecek büyük ekonomilerden birisi olmuştu. 1920'li yılların başında ülkelerin geçirdikleri ekonomik süreçler birbirlerinden farklılaşmıştır. Belçika, Fransa ve İtalya'da genişleyici para ve maliye politikaları fiyatlar genel seviyesini artırmasına rağmen hızlı büyüme ve düşük işsizlik oranları gerçekleşmiştir. Almanya büyük yatırımlarla hızlı bir büyüme sürecini 1923 Hiperenflasyon deneyimindeki kırılma hariç sürdürebilmiştir. İskandinav ülkeleri ise kendi aralarında Batı ekonomisinin tersine deflasyonist politikaları tercih etmişlerdir. İngiltere ise savaş öncesi sterlin paritesinde kalabilmeye yönelik politika tedbirlerinde israr etmiştir.27

İki Dünya Savaşı arasındaki dönemde Amerikan ekonomisi büyük bir toplumsal kalkınma sürecinin yaşamaktadır. Amerikan ekonomisinin ortalama yıllık \%4,7 oranında büyüdüğü, işsizlik oranlarının \%3,7 yıllık ortalamaya sahip olduğu dönem toplam gelirler içinde zengin sınıfın \%24 den \%33,5’a çıkmasıyla büyük bir ekonomik patlama geçirmiştir. Milyoner sayısı 1922 yılında 7.000 civarında iken 1929 yılında 30.000 'e çıkmıştır. Otomobil sektörü yüzyılın başından itibaren 4 milyon araç üretmiş, banliyö mahallerinde büyük ve pahalı konut projeleri artmış ve her üç Amerikan ailesinden ikisi sosyal statü kimliği olarak araç sahibi olabilmiştir. Geniş tüketici kitlesinin teknolojik buluşlar sayesinde soğutucular, elektrikli ev aletleri gibi yeni tüketim mallarıyla tanışması ekonomiye bir dinamizm kazandırmıștır. Büyük fonların taksitli krediler olarak tüketicilere sunulması bu dinamik ekonomi içinde

${ }^{27}$ Angus Maddison, "The World Economy In the 20th Century", Development Centre Studies, OECD Publishing, 1989, ss. 51-52. 
büyük bir alım gücüne neden olurken aynı zamanda toplumun çoğunu da kredi borçlusu haline getirmiştir. ${ }^{28}$ Aşağıdaki tablo bize 1920-1930 arası Amerika'da on yıl içinde seçilmiş tüketim malları mülkiyet oranlarındaki değişimi göstermektedir. Birinci Dünya Savaşı sonrası Amerikan sanayi ürünleri artışı tüketicilerin ilgili dönemin koşullarına göre daha fazla teknolojik ürün sahibi olabilmelerine imkân sağlamıștır. ${ }^{29}$

\section{Tablo 1: Amerikalıların Seçilmiş Mal Gruplarına göre Mülkiyet oranları}

\begin{tabular}{|l|l|l|}
\hline Mal kalemleri & $\mathbf{1 9 2 0}$ & $\mathbf{1 9 3 0}$ \\
\hline Araba & $\% 26$ & $\% 60$ \\
\hline Radyo & $\% 0$ & $\% 46$ \\
\hline Elektrikli Aydınlatma & $\% 35$ & $\% 68$ \\
\hline Çamaşır Makinesi & $\% 8$ & $\% 24$ \\
\hline Elektrikli Süpürge & $\% 9$ & $\% 30$ \\
\hline Alafranga Tuvalet & $\% 20$ & $\% 51$ \\
\hline
\end{tabular}

Kaynak: Stanley Lebergott, "Pursuing Happines: American Consumers in the Twentieth Century", Princeton University Press, 1993, s: 102, 113, 130, 137.

Üretim ve tüketim toplumu olarak getirilen ekonomik disiplin ulusal çıktı artışlarıyla ortalama değerlerin üstünde seyrettikçe reel sektörün dışındaki alanlarda da varlık değerleri üzerinde spekülatif hareket ve etkiler artmıştır. Finansal sahadaki bu varlık değerleri şişmeleri sürerken reel sektörde 1928 sonrası ulusal çıktı artışlarını belirleyen etmenlerden biri olan kişi başına düşen ulusal çıktı oranları ise hızını kaybetmeye ve gerilemeye başlamıştır. $\mathrm{Bu}$ negatif sapma ise dönem içinde piyasa mekanizmasına duyulan güven gereği bir çöküşün ön belirtisi olarak görülmemiştir. Aşağıdaki grafik Büyük Depresyon öncesi ve sonrası kişi başına düşen ulusal çıktı rakamlarını göstermektedir. ${ }^{30}$

28 Jon D. Wisman \& Barton Baker, "Rising Inequality and Financial Crises of 1929 and 2008", www.american.edu/cas/economics/, s. 1-34.

${ }^{29}$ Stanley Lebergott, Pursuing Happines. American Consumers in the Twentieth Century, Princeton University Press, 1993, s. 102,113,130,137.

30 Timothy Kehoe, Edward C. Prescoot, "Great Depressions of the 20th Centrury", Review of Economic Dynamics 5,2002, www.idealibary.com, s. 2. 
Sayfa/Page | 92

İGÜ Sos. Bil. Derg.,

4 (1), 2017, ss. 77-127.

\section{Grafik 1. : Sanayi Ülkeleri Kişi Başına Düşen Ulusal Çıktı}

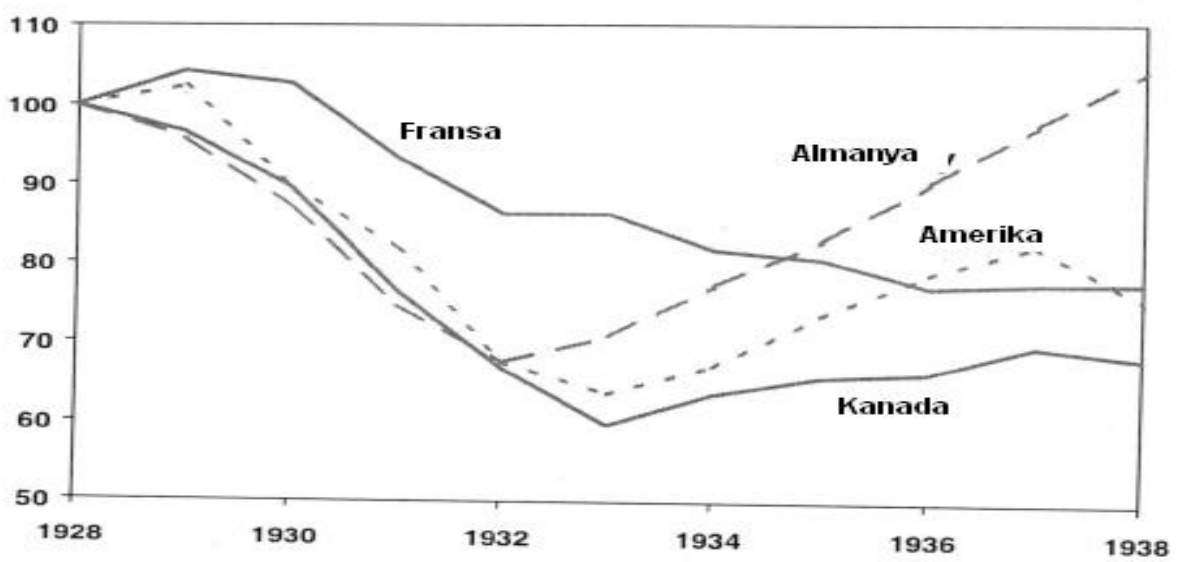

Kaynak: Timothy Kehoe \& Edward C. Prescoot, "Great Depressions of the 20th Century”, Review of Economic Dynamics 5,2002, www.idealibary.com, s. 2.

Amerikan ekonomisindeki 'Altın Yıllar' olarak adlandırılan canlanma kendini New York borsasında da hissettirmeye başlamıştır. Özellikle menkul kıymetlerin değerlerinin spekülatif artarak sanayi endeks rakamlarının iki katına çıkmasına neden olmuştur. ${ }^{31} 1927$ ilkbaharından itibaren ucuz banka kredilerine ve banker ödünçlerine onay veren Amerikan Merkez Bankası'nın bu tür genişleyici para politikası çoğu teorisyene göre menkul kıymetler borsasının spekülatif patlamasının nedeni olarak görülmüștür. 32 Spekülatif hareketlenmeler sonucu Amerikan toplumu içinde düşük gelirli insanlar bile tasarruf yaratarak ya da borçlanarak borsada işlem gören yüksek getirili menkul kıymet alımına başlamışlardır. Menkul kıymetler borsasındaki bu hareketlilik sonucu Amerika'daki farklı bölgelerde yer alan 29 tane borsa piyasası içinde 1.548 .707 tane müşteri hesabı oluşmuştur. 120 milyon Amerikalının yaklaşık 30 milyonluk kısmı aktif olarak bir şekilde borsayla bir şekilde alım satım bağı bulunmaktaydı. Bunların içinden yaklaşık bir milyon kişi spekülatör olarak anılıyordu. Bu spekülatörlerin yaklaşık üçte ikisi ise ellerinde hiç nakit para bulundurmadan açığa spot alım ve satım yapan kişilerden oluşuyordu. Borsadaki açığa alım ve satım ticaretinin büyümesi menkul kıymet fiyatlarının yükselmesine ve yatırım kredilerinin tehlike yaratacak ölçüde artmasına neden olmuştur. Geleneksel olarak hisse senetleri ücret ve maaşlardan on kat daha fazla kazandırmış ve artık sermaye kazançları kendi başına değer kazanarak daha fazla yatırım kredisi

${ }^{31}$ Sumru Öz, "Kriz ve Korumacılık: Tarih Tekerrür Edecek mi?”, TÜSİAD-KOÇ UNIVERSITY ECONOMIC RESEARCH FORUM, Temmuz 2009, s. 11, www.ku.edu.tr/ EAF/0904.

32 Micheal Bordo \& Olivier Jeanne, "Boom-Busts in Asset Prices,Economic Instability and Monetary Policy", NBER Working Papers, No: 8966, s. 6, www.nber.org/papers/ w8966 
yaratmıştır. Tablo 21922 yılından itibaren New York borsası menkul kıymetler fiyatlarının spekülatif nitelikte arttığını göstermektedir. 33

\section{GRAFIK 2. : 1922-1940 MENKUL KIYMETLER FIYATLARI}

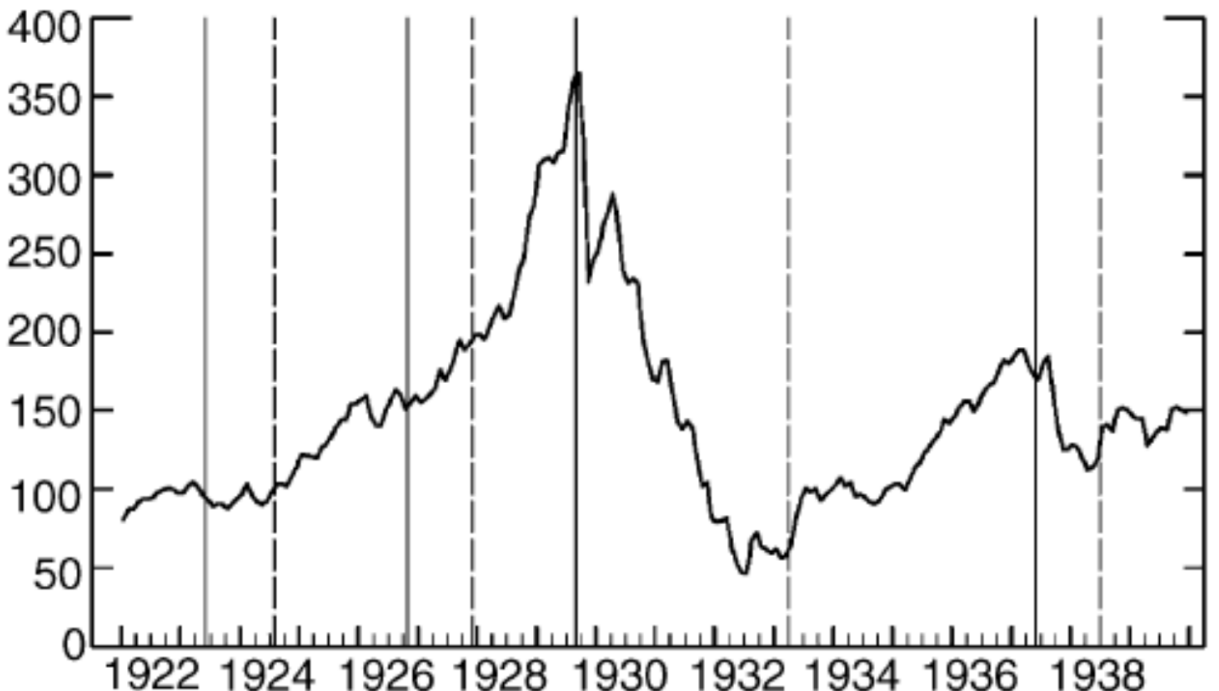

Sayfa/Page | 93

IGU J. Soc. Sci.,

4 (1), 2017,

pp. 77-127.

Kaynak: Athanasios Orphanides, "Monetary Policy in Deflation: The Liquidity Trap in History and Practice", North American Journal of Economics and Finance, 15, 2004, s. 106.

Yatırım kredileri artışı 1920'li yıllar sonralarına doğru bankacılık sektöründe de sıkıntılar doğurmuştur. 1929 Büyük Buhranda Menkul Kıymetler Borsası çöküşü banka sektörünün de krize girmesine neden olmuştur. 1920 sonrası kırsal alanda faaliyet gösteren ufak ölçekli bankaların çoğu artan borç zararlarından dolayı iflas etmiştir. ${ }^{34}$ Yaşanan bir sürü iflaslar neticesinde 1930 yılındaki Amerikan sosyal hayatındaki manzara ise ekonomik çöküşün acı tablosunu sergilemektedir. İşsizlik oranı \%25 seviyesini geçmiş ve evsizlerin sayısı artmıştır. İpotekli ev ve çiftlik alımında bulunanların çoğu geri ödeme yapamadıkları için evsiz ve işsiz kalmışlardır. Kırsal kesimde panikleyen mevduat sahipleri paralarını geri çekmek için harekete geçmiş ve yerel bankalarını kısa sürede iflasa sürüklemişlerdir. ${ }^{35}$ Kırsal alandaki bu banka iflasları finans şebeke ağı içindeki merkez şehir bankaları da etkilemiş ve büyük banka paniklerine neden olmuştur. Bir kısım

33 Murray N. Rothbard, America's Great Depression, Mises Institute Publishing, 5. Edition, 2000, ss. 214-215.

34 Gary Richardson, "Categories and Causes of Bank Distress During the Great Depression, 1929-1933”, Explorations in Economic History, Volume 44, 2007, www.sciencedirect.com, ss. 588-589.

35 Greg Hansen ve Dimitri Papadimitri, "Did the New Deal Prolong or Worsen the Great Depression?”, Challenge, Vol: 53 No: 1, 2010, s. 64. 
Sayfa/Page | 94

İGÜ Sos. Bil. Derg.,

4 (1), 2017, ss. 77-127.

teorisyen ortaya çıkan banka paniklerinde mevduatların geri çekilmesini, alacakların ödenememesini ve Federal Rezerv Bankasının müdahaledeki isteksizliğini aslı nedenler olarak görmektedir. Bankacılık sektöründe Büyük Depresyon öncesi yaşanan banka panikleri mevduatların çekilmesiyle sonuçlanmıştır. Nakde dayalı hisse senetlerine yönelik varlıklara artan ilgi sonucu bankalardan çekilen reel varlıklar diğer finans kurumlarına akmaya başlamıştır. Bu durum menkul kıymetler piyasasında finansal balon yaratacak kazançları büyüterek daha öncede ifade edilen kontrolsüz bir yatırım piyasası yaratmıştır. ${ }^{36} \mathrm{Bu}$ koşullar altında Amerikan Merkez Bankası'nın Büyük Depresyon öncesi ve sonrasındaki izleyebileceği para politikaları literatür içinde genelde iki ayrı görüşe dayanmaktadır. Birincisi Merkez Bankası'nın süreci savsaklama ve önemsizleștirme niteliğindeki başarısız girişimleri, ikincisi ise bürokratik eylem alanını genişletmeye ve bir takım menfaat gruplarını tatmin edecek bilinçli sıkı para politikalarına izin vermesine dayalıdır. Dönemin Merkez Bankası yetkilileri de sermaye piyasası balonlarının önüne geçmek için yapmış oldukları açık piyasa satışlarının ve ıskonto oranları artışlarının iradi bir enflasyon oluşturacağını düşünmüşlerdir. Para otoritelerinin iradi bir enflasyon yaratma endișelerinden dolayı varlık balonların üzerindeki bu tür müdahalelerden kaçınılmıştır. ${ }^{37}$ Merkez Bankasına getirilen temel eleştiri on yıllık süreç içinde sermaye piyasası dalgalanmalarını dikkate almayıp Borsa çöküşüyle beraber panik reaksiyon göstermesidir. 1929 yllının içinde hisse senedi değerleri ile faiz oranları arasında göze çarpacak bir negatif ilişkinin varlığı ve arkasından Merkez Bankasının yükselen hisse senedi değerlerine faiz oranlarını artırarak reaksiyon göstermesi Amerikan ekonomi tarihi içinde değişim yaratacak bir dönüm noktası yaratmıştır. Daha da önemlisi menkul kıymetler piyasasındaki yüksek volatilite politika yapıcıları arasında bir müdahalenin yapılıp yapılmaması konusundaki fikir ayrılıklarını da büyütmüştür. Sonuç olarak karar alma sürecindeki uyum eksikliği para politikalarının Büyük Depresyonun şiddeti üzerindeki etkiyi zayıflatmıştır. ${ }^{38}$

1929 Büyük Depresyonun açlklanmasına yönelik çalışmaların çoğunda ise dönemin para sistemi ön plana çıkartılmıştır. Çalışmaların çoğunda Altın Standardı sisteminin Büyük Depresyonunun uzun ve şiddetli sürmesine neden olduğu konusunda hemfikir olunmuștur. Sabit kur sistemine dayalı altın kambiyo standardı birçok teorisyene göre ülkeler arası finansal kargaşanın

36 Gary Richardson, a.g.e., s. 590.

37 Charles Calomiris \& David Wheelock, "Was the Great Depression a Watershed for American Monetary Policy" in The Defining Moment: The Great Depression and The American Economy in the Twentieth Century, Ed. Micheal Bordo, NBER Onlinebook, www.nber.org/chapters/c6887, 1998, ss. 24-26.

38 Pierre L. Siklos, "The Fed's reaction to the stock market during the great depression: Fact or artefact?", Explorations in Economic History, Volume 45, 2008, s. 182,

www.sciencedirect.com 
yayılmasına ve para politikalarının bu kargaşayı çözmesine engel olmuştur. Amerika'nın 1928 sonrası izlediği sıkı para politikası ise sıkça kriz dönemine girilmesinin bir gerekçesi olarak eleştirilmiștir. Sorun Amerikan Merkez Bankası'nın neden böyle bir dönüşüm niteliğinde karar almasıyla ilgili olmuştur. Fransa Merkez Bankası'nın dünya altın rezervlerindeki payını 19271932 arası \%7'den \%27'ye çıkarması ve 'altının istiflenmesi' rezervlerde suni bir kıtlık yaratmıştır. Bu durum Amerika dahil bir çok ülkeyi büyük bir deflasyonist baskıya doğru itmiştir. Fransa Merkez Bankası'nın bu altın istifleme süreci Amerika'dan 1929-1933 arası yayılan deflasyon sürecinin ve Amerikan Merkez Bankası'nın tepki hareketlerinin bir nedeni olarak görülmektedir. Şayet Merkez Bankaları 1928 yılındaki altın rezerv oranlarını değiştirmeden muhafaza etselerdi yayılan deflasyonun önüne geçilebileceği savunulmuştur. Böyle bir durumda Amerikan Merkez Bankasının Büyük Depresyona yönelik eleştirilen tepkisel para politikası hareketinin gerçekleşmeyeceği düşünülmektedir. ${ }^{39}$ Ticari Kapitalizmin sonu olarak görülen 1929 Büyük Depresyon öncesi yaşanan deflasyon yüksek kapasiteli çalışan endüstrilerin bile fiyat düşürmelerine neden olmuştur. Bunun neticesinde sermaye varlıklarının finansmanı için alınan borçlar ödenemez hale gelmiş ve işsizlik oranı \%25 artarken varlık fiyatları \%85 değer kaybetmiştir. 1929 Büyük Depresyonun açıklanmasında Minsky'nin Finansal İstikrarsızlık Hipotezi de krizlere bakışta yenilik yaratmıştır. Finansal istikrarsızlık hipotezine göre kapitalist ekonomilerde varlık fiyatlarının azalması sonucu oluşan borç deflasyonu borç deflasyonlarını artırarak zincirleme bir etki yaratmakta ve önüne geçilmek için alınan kamusal tedbirler ise 1929 Büyük Depresyon örneğindeki gibi yetersiz kalmaktadır. ${ }^{40}$

Irving Fisher 1929 Büyük Depresyon'u “Borç-Deflasyon Teorisi” başlığı altında incelemiştir. Fisher'e göre iktisadi daralmaya giriş döneminin belirleyicileri aşırı borçlanma ve deflasyon olgusudur. Ekonominin genleşme dönemlerinde yatırımcların büyük kazanç beklenti içinde olmaları onları daha yüksek bir borçlanma ve varlıklar üzerine yatırım yapmaya itecektir. Gerçekleşen yüksek borçlar ekonomide likitide sıkışıklı̆̆ı sonucu panik havası yaratarak varlık piyasasındaki geri satış işlemlerini hızlandıracaktır. Geri satışlar arttıkça varlık fiyatlarının değer kaybı başlayacak ve borçluların yükü artmış olacaktır.41 Fisher Büyük Depresyon döneminde borçlanma ve deflasyon ilişkisi doğru varsayılsa bile fiyat seviyesi kontrol sorunun daha önemli olduğunu ileri sürmüştür. Fisher kontrol mekanizmasında yetkili

39 Douglas A. Irwin, "Did France Cause the Great Depression?", NBER Working Paper No. 16350, September 2010, http://www.nber.org/papers/w16350, s. 1, 36.

40 Ersan Bocutoğlu, "Hyman P. Minksy'in Konjonktür Teorisi 2007-2010 Küresel Krizi Açıklamaya Uygun mu? Heterodoks Değerlendirme”, Bankacılar, Türkiye Bankacılar Birliği Yayını, Sayı 75, Aralık 2010, s. 10 ve 14.

41 Suat Oktar \& Levent Dalyancl, "Finansal Kriz Teorileri ve Türkiye Ekonomisinde 1990 Sonrası Finansal Krizler”, Marmara Üniversitesi I.I..B.F. Dergisi, Cilt 19, 2010, s. 7.

Sayfa/Page | 95

IGU J. Soc. Sci., 4 (1), 2017, pp. 77-127. 
Sayfa/Page | 96

İGÜ Sos. Bil. Derg.,

4 (1), 2017,

ss. 77-127.

organ olarak Amerikan Merkez Bankası Yönetim Kurulu ve Hazine İdaresinin de yeni bir sorumluluk anlayışı üstlenmelerinin beklenildiği vurgulamıştır.. Fisher'e göre fiyat seviyesi kontrolü dolar sahasının kontrolü depresyon sürecinin yegâne çözümü olamamaktadır. İstikrarlı ideal bir dolar sahası gerçekleşse bile maruz kalınan borç sarmalı, teknoloji dönüşümü ve işsizlik sorunu, biriken üretici artıkları, fiyatların kayması (price dislocation) gibi olaylarla karşı karşıya kalınmıştır. Fisher bütün bu problemlerin çözümü için doların kendileri tarafından yok edilmesi için araştırmacıların uzun uğraşlar vermesi gerektiğini savunmuştur. Aynı zamanda borç deflasyon teorisinin geçmiş ve gelecekteki depresyonlar için bir deneyim teşkil edeceğine inandığını da belirtmiştir. ${ }^{42}$

1929 Büyük Depresyonun açılklanmasında altın para standardı sisteminin varlığı ve 1 . Dünya Savaşı sonrası yeni politik sınırların çizilmesiyle savaş tazminat taleplerinin getirdiği altın tabanlı ödeme akımlarının yön değiştirmesi de birçok araştırmacının üzerinde durduğu temel noktalardan birisi olmuştur. Bazı araştırmacılar Büyük Depresyonu anlayabilmek için savaş öncesi altın standardının İngiltere merkezli hegemonik bir sistem olarak sorgulanmasının da gerekli olduğunu ileri sürmektedirler. İki savaş arası dönemde İngiltere'nin güç kaybı, Amerika Birleşik Devletleri'nin yarattığı yeni hegemonik saha içindeki tecrübesizliği ve kendini yeni düzenden tecrit etme girişimleri eleştirilmiştir. Yaratılan bu ortamda ulusal merkez bankaları arasında uluslararası finans alanının organizasyonu için yeterli iş birliğinin oluşturulamaması da para sistemi düzensizliğinin bir gerekçesi olarak görülmektedir. ${ }^{43}$ Nitekim Charles Kindleberger de Büyük Depresyon ile ilgili analizlerinde 1. Dünya savaşı sonrası Londra'nın uluslararası ekonomiyi stabilize edecek etkin bir finans merkezi olma becerisini kaybettiğini ileri sürer. Bu yüzden Amerika'nın başı çektiği ve İngiltere'nin takip ettiği iki başlı finans liderliği sonucunda oluşan etkinsiz hegemonik güç eksikliği 1929 Depresyonun nedenlerinden biri olarak görülmüştür. Kindleberger'e göre hegemon ülkenin para otoritesinin yardıma ihtiyaç duyulan ekonomilere yapacağ fon takviyeleri depresyonu engelleyecektir.

Büyük Depresyonun tamamen parasal güçlerin hareketlerinin neden olduğunu savunan Milton Friedman'a karşı Peter Termin konuya ilişkin eserlerinde Friedman'ın tezine karşı çıkmıştır. Altın standardının korunma zorunluluğu ile ortaya çıkan deflasyonist baskıya dikkati çekmekle beraber deflasyonun ekonomi üzerindeki etkilerinin tahmin edilebilmesinin zor olduğunu ama gidilen istikametin depresyonu tetiklediğini iddia etmiştir.

${ }^{42}$ Irving Fisher, "The Dept Deflation of Great Depressions", Econometrica, No: 1, ss. 347-349.

${ }^{43}$ Ben Bernanke \& Harold James, "The Gold Standart, Deflation, and Financial Crisis in the Great Depression: An International Comparison", NBER Working Paper No: 3488,

October 1990, http://www.nber.org/papers/w3488, ss. 6-7. 
Galbraith "Büyük Çöküş-1929" isimli kitabında Depresyonun açıklanmasını hisse senedi piyasasındaki spekülatif hareketlere dayandırmaktadır. Tarihteki bütün spekülatif hareketlerin er ya da geç ekonomiyi hasara uğratacak bir sonla biteceğini ifade etmiştir. Bu görüşünün yanında bir taraftan reel sektör ve stok fazlaları üzerinde dururken diğer taraftan ise ekonominin beş ayrı zayıflıktan ötürü sağlam temellere oturmadan gelişim süreci içinde bulunduğunu savunmuştur. Bu beş zayıflığı gelir dağılımındaki kötü dağılım, kötü şirket yapıları, zayıf bankacılık yapısı ve bankacılık sisteminin kolay kırılganlığı, Amerika dâhil dış ticaret bilançoların kırılgan yapısı, ülkeler arası dış ticaret dengelerinin tutarsızlığı ve 1929 Çöküşüne kadarki öngörülerin ekonomi bilgisi zayıflığı nedeniyle gerçeklere ışık tutacak nitelikte olmadığı şeklinde gruplandırmıştır. Süreci gelir dağılımı açısından incelediğimiz de 1920'li yıllar sonrası büyüyen Amerikan ekonomisinde en yüksek gelir diliminin nüfus içindeki payı yüzde beșe eşit iken bu yüzde beşlik grup toplam gelirin üçte birini elde etmiştir. Dönemin şirket yapıları şirket sahtekârlıkları ve dolandırıcılıkları içinde fazlasıyla barındırmaktaydı. Holdingleşme süreci Amerika'da işletmelerin birbirlerinden çok farklı sektörlerde faaliyette bulunmalarına da izin vermiştir. Bankalar açısından durum çok daha kötü bir durumda seyretmiştir. Zira bankaların sermaye yapılarının zayıflığı ve ödeme problemleri sorununda kendilerini savunabilecek bir teminat mekanizmasının yokluğu domino etkisiyle birçok zayıf ve kuvvetli bankanın iflasına neden olmuştur. Amerika ve diğer ülkelerin dış ticaret bilançoları kötü yönetim sonucu Amerika en büyük alacaklı kreditör ülke konumunda kalırken diğer ülkeler ise ticaret dengelerinin açıklarını uzun bir dönem kapatmak için mücadele ettiler. $\mathrm{Bu}$ sürece dönemin ekonomi bilgisinin zayıflığı ve çaresizliğinin de ilave olması Galbraith'e göre toparlanma süresini uzatmıştır. ${ }^{44}$

Peter Termin Büyük Depresyonla ilgili eserinde dönemin altın standardı sisteminin ve savaş sonrasındaki ülkelerin yeni pozisyonlarının 1929 yılındaki çöküntüyle derin bir bağlantısının olduğunu savunmaktadır. Ona göre savaş sonrasındaki koşulların altın standardı kurallarında bir yeni düzenleme yapılmasını zorlaştırmıştır. Termin'e göre 1. Dünya Savaşının yarattığı şok, değişmeyen uluslararası kurumlar ve taviz vermez politik rejimler büyük depresyonu yaratmıștır. 1925'ler sonrası altın standardı kurallarının esnetilememesiyle beraber tüketici ve üretici fiyat endeks değerlerinin azalma sürecinde bulunduğu tespit edilmiştir. Grafik 21926 sonrasından itibaren Amerikan tüketici ve üretici fiyat endekslerinin nasıl bir azalan seyir izlediğini ve deflasyon sürecinin yaşandığını göstermektedir. 45

44 John Kenneth Galbraith, Büyük Kriz-1929, Pegasus Yayınları,2009, ss. 185-191.

45 Peter Termin, Lessons from the Great Depression, The MIT Press, 1989, s. 33.

Sayfa/Page | 97

IGU J. Soc. Sci., 4 (1), 2017, pp. 77-127. 
Sayfa/Page | 98

İGÜ Sos. Bil. Derg.,

4 (1), 2017, ss. 77-127.

GRAFIK 3:

\section{TÜKETICi VE ÜRETICI FIYAT ENDEKSi}

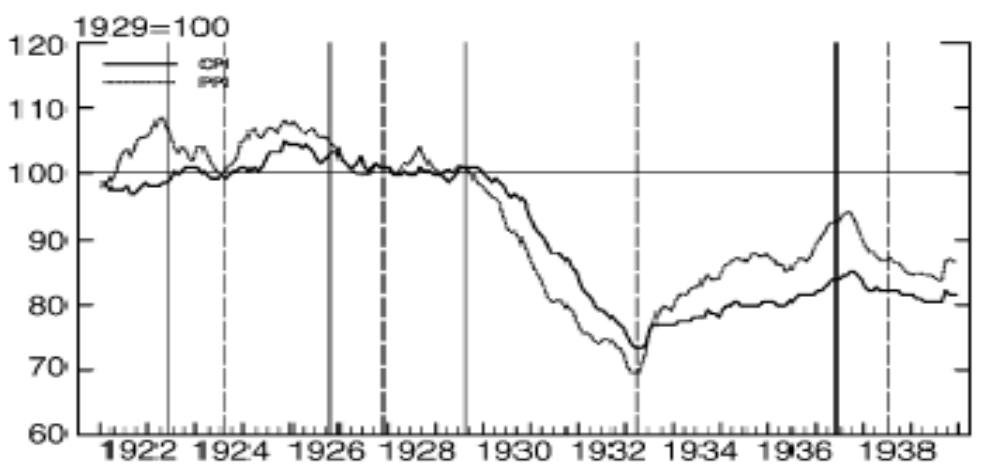

Kaynak: Athanasios Orphanides, "Monetary Policy in Deflation: The Liquidity Trap in History and Practice", North American Journal of Economics and Finance, 15, 2004, s. 106.

1930’lu yıllara doğru yaşanan deflasyon sürecinde Milton Friedman da Büyük Depresyonun açıklanmasının arkasında biri dizi ufak nedenlerin olduğunu ama dikkate alınmayan bu ufak nedenlerin büyük sonuçlar doğurmuş olduğuna dayalı açıklamalarda bulunmuştur. Buna örnek olarak Depresyonu 1928 yılında New York Merkez Bankası'nın altın standardı sisteminin taraftarı olan müdürü Benjamin Strong'un ölümü ile bile ilișkilendirmesidir. Friedman Lewis ile yaptığı ileriki ortak çalışmasında ise Depresyonun kaynağının Amerika'daki olaylardan kaynaklandığını ve savaş sonrası Amerika'ya akan yoğun altının Amerikan ekonomisinin sonunu hazırladığını ifade etmiștir. Bu görüş uzun yıllar şiddetle reddedilse de geniş bir görüş onayı almıştır. Altın standardının bir çıkmaza gireceği fikrinin ısrarla kabul edilmeyişi deflasyonist süreci uzatmış ve Büyük Depresyonu yaratmıştır. Altın yıllar olarak nitelendirilen 1920'li yılların ilk yarısından itibaren tarım ve ham metal üretim değerleri kapasitelerin üstüne çıkarak aşırı bir üretim fazlalığı yaratmıştır. Bu durum ürün fiyatlarının düşmeye başlamasına neden olmuştur. Satın alım destekleme politikalarının da fiyat azalışlarına çözüm üretememesi yüklü miktarda stokların elde tutulma maliyetlerini artırmıştır. Özellikle tarım ve maden stoklarını elde tutmaya çalışan işletmeler zaman içerisinde iflas ederek varlıklarını kaybetmeye başlamışlardır.

Deflasyon sürecinin uzunluğu sadece Amerikan ekonomisinde değil dönemin diğer Avrupa kıtası sanayi ülkelerinde de yaşanmıştır. Altın standardının birçok ülkede korunmak istenmesi Büyük Depresyonu yaratan nedenlerden bir tanesidir. Sistemin uyarlanma süreci deflasyonist baskının görülmemiş şiddette ve derinlikte dünya çapında yayılmasına neden olmuştur. 
Aynı zamanda bu baskı ekonomik aktivitelerin belli aralıklarla kesilmesinde de etki göstermiştir. Grafik 3 bize 1926 sonrası dönemin dört büyük güçlü ekonomisinin nasıl birbirlerini etkileyerek bir deflasyon süreci içine girdiğini göstermektedir. ${ }^{46}$ Büyük Depresyona yönelik Monetarist bakışın ileri gelenleri de Amerikan Merkez Bankasının daraltıcı politikalarını Büyük Depresyonun ve deflasyonist etkinin uzamasının başlıca nedeni olarak görmüşlerdir. Buna ek olarak güdümlü uluslararası altın standardının 1.Dünya Savaşı sonrasında bir dizi şoklar yaratarak ülkelerin altın rezervlerini korumak için birbirleriyle çelişen iktisat politikalarına yönelmeleri de olmuştur. ${ }^{47}$

\section{GRAFiK 4: Büyük Depresyon Dönemi Gelişmiş Sanayi Ülkeleri Enflasyon Oranları}

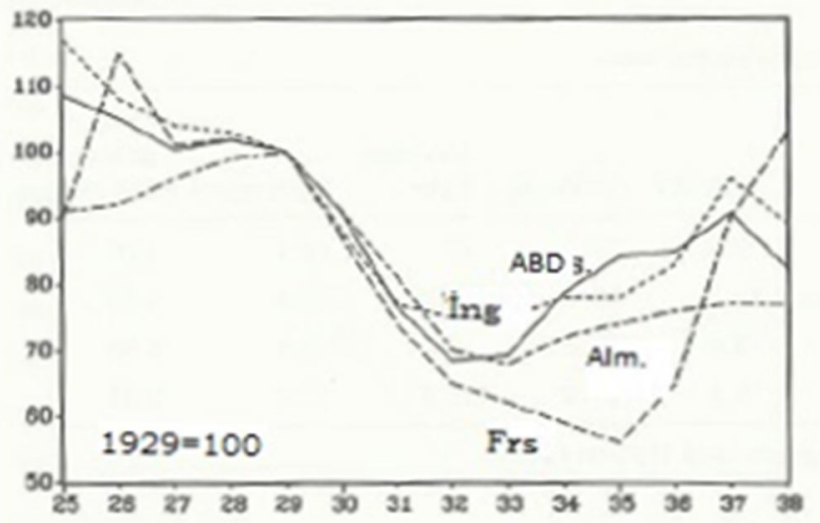

Kaynak: Peter Termin, Lessons of Great Depression, MIT Press, 1998, s. 4.

Büyük Depresyon öncesi başta Amerika ve Avrupa Kıta ülkelerindeki deflasyon süreci en göze batan sorunlardan bir tanesi olmuștur. Depresyon öncesi deflasyon sürecini gözleyen dönemin kuramcıları ve politika yapıcılarının bunu göz ardı etmeleri bir ihmal midir sorusu ancak dönemin iktisat öğretileri içinde değerlendirilmelidir. Hem "görünmez el" ve "Pazar her şeyi çözer" görüş birliğinin geçerli olması hem de dönemin Merkez Bankacılı̆̆ tanımının ve fonksiyonelliğinin tam yerine oturmayışı sonucu fiyat istikrarının altın kambiyo standardının devamıyla sağlanacağı düşüncesine hakim olmuştur. Dönemin politikacıları için 'Depresyon' ve 'Enflasyon' her zaman birbirleriyle yer değiştirilebilir kavramlar olarak algılanmıştır. Bu algı 20. yy. içinde Amerikalı politikacılar başta olmak üzere Avrupalı politika yapıcıları için geçerliliğini uzun bir süre korumuştur. Dönemin Alman Şansölyesi Heinrich Bruning'in İngiliz Başbakanı'na "Ya deflasyonla yaşamak zorunda kalacağız ya da paralarımızı devalüe edeceğiz. Enflasyonsuz altı yıl başarılı bir

46 Peter Termin, a.g.k., s. 34, 38.

47 Paul Burkett, "Forgetting the Lessons of Great Depression", Review of Social Economy, Spring 1994, Vol: 52, Issue 1, ss. 70-71.

Sayfa/Page $\mid 99$ IGU J. Soc. Sci., 4 (1), 2017, pp. 77-127. 
Sayfa/Page | 100

İGÜ Sos. Bil. Derg.,

4 (1), 2017, ss. 77-127.

süreçten sonra fiyatlar genel seviyesinin ufak adımlarla bile artmasına izin vermemiz artık mümkün değildir" konuşması dikkat çekicidir. Dönemin politika yapıcılarının deflasyon gerçek ve tehlikeli bir boyutta olsa bile enflasyondan ne kadar korktuklarını göstermektedir. Depresyonun derinliklerde yatan bu tür ürkütücü gerçekleri ise politik iktisat evriminin saplantılarında bulabilmekteyiz. ${ }^{48}$

1929 Büyük Depresyonunun oluşumunda Amerikan iç ekonomi politikaları ne kadar önem içeriyorsa aynı zamanda 1893 Panik süreci ve sonrasındaki iç politika süreci de bir o kadar önem taşımaktadır. 19. yüzyılın ortasında Amerika toplumu kırsal yaşamdan endüstriyel kentli yaşamına kaymaya başladıkça politik açıdan bu değişim şiddetle arzulanmıştır. Uzun zaman yönetimi elinde tutan Cumhuriyetçiler toplumun yeni politik dönüşümü karşısında yenilerek 1890 sonrası yönetimi Demokratlara teslim etmek zorunda kalmışlardır. 1890 Amerikan seçimleri Demokratların ulusal seçim tarihinde hem Beyaz Saray'ın kazanılması hem de Kongrenin kurulmasında aynı anda göreve geldikleri ilk seçim olmasıyla farklılık yaratmıştır. Fakat 1893 Panik süreci Demokrat Partinin ciddi bir güvenoyu kaybetmesine neden olmuş ve 1894 seçimlerinde ülke yönetimi 1930 yılına kadar Cumhuriyetçilerde kalmıştır. Tarihin bir tekerrürü olarak 1929 Krizi de Cumhuriyetçilerin aleyhine işlemiş ve seçimlerde eyaletlerin çoğunda Demokrat aday Herbert Hoover kazanmıştır. Bu durum Amerikan ekonomisindeki krizlerin oluşum zamanı ile politika yönetimi dönüşüm tarihleri arasında büyük benzerliklerin olduğunu göstermektedir. ${ }^{49}$

\section{Büyük Depresyon'un Belirli Avrupa Ülkelerindeki Etkisi (Avusturya-Almanya Örnekli)}

1929 Büyük Depresyon Amerika ekonomisinde ciddi bir çöküş süreci yaşatmakla kalmamış bunu takip eden yıllarda Avrupa kıtasında yer alan sanayi ülkelerinde de kademeli bankacılık krizlerine ve reel sektör durgunluklarına yol açmıştır. Avusturya Macaristan İmparatorluğunun en büyük bankası olan Credit-Anstalt'ın 1931 Mayısında iflas etmesi Avrupa kıtası içinde en dikkat çekici örneklerden bir tanesidir. Credit-Anstalt 1855 yılında uzun bir yüzyılın tanınmış Rothschild ailesi tarafından kurulmuştur. Banka sadece klasik bir ödünç kurumu olmakla kalmamış, Amerika kıtası dahil bir sürü ülkede şeker üretiminden araba yapımına kadar farklı sektörde işletmecilik ve yatırım ortaklıklarına sahip olmuştur. Böyle büyük bir bankanın ve ticaret kuruluşunun iflas etmesi Kıta Avrupası içinde yer alan bir

${ }^{48}$ Barry Eichgreen, Harold James, Golden Fetters: The Gold Standart and the Great Depression, 1919-1939, Oxford University Press, 1992, ss. 23-24.

${ }^{49}$ Robert S. McElvaine, The Great Depression; America, 1929-1941, Three River Press, 2009, s. 62. 
çok finans kurumunun domino etkisiyle yıkılmasına neden olmuştur. Birinci Dünya Savaşı sonrası ulusal dengelerin bozulmasına rağmen Credit-Anstalt Bankası'nın eski ticari ve finans düzeninde kalma arzusunun Banka'nın iflasına neden olduğu ileri sürülmüştür. Amerikan Bankacılık sistemine göre daha zayıf bankacılık düzenlemelerine sahip Avrupa'da şirket ortaklıkları fazla olan Credit-Anstalt ciddi zarar kayıpları ile karşılaşmaya başlamıştır. Bu durum bankadan ciddi boyutlarda mevduat çekilmesine neden olmuştur. Bankanın varlıklarını yeniden değerlendirmeyi reddetmesi ve zarar kayıplarını haftalar sonra açıklaması banka üzerindeki güven kaybını artırmış ve mevduat çekişlerini hızlandırmıştır. Bu süreç Banka için tasarruf bırakılacak kadar büyük ama aynı zamanda iflas edecek kadar da büyük tanımlamasını getirmiștir (toto biy. to sav, toto biy. to fail).50 Cedit Ansal Bankasının Avusturya ekonomisi için büyüklüğünü sayılarla ifade etmek gerekirse 1930 yılında bankanın bilanço değeri Avusturya hükümetinin kamu harcamaları büyüklügünde ve Avusturya şirketlerinin yüzde 69'u ile ticari ilişki içindeydi. Bu şirketlerin yüzde 15 'inin ise bankaya ciddi miktarlarda kredi borcu bulunmaktaydı. Bankanın başında Rothschild ailesinden Louis Rothschild'ın olması bankaya büyük Alman bankalarından daha fazla itibar vermekteydi. Bankanın 1930 yılı içindeki zarar kayıpları toplam bilançosunun yüzde 7,5' una denk gelmekteydi ve bu da öz sermayesinin \%85'ine denk geliyordu. Ortalama 140 Milyon Schilling ulusal para kaybının olduğunu gecikmeli açıklayan banka iflasıyla iltimaslarla büyüttüğü Avrupa kredi ve finans sahasında çok ciddi bir domino etkisi yaratmıştır.51

1929 Büyük Depresyon etkileri sadece Avusturya sınırları içinde Cedit Anstalt Bankası'nın iflası ile sonuçlanmamış, Alman Bankaları da finansal yönden sıkıntıya girmişlerdir. Alman Bankaları 1920 sonrası ulusal tasarrufların zayıflığı ve kararsızlığı nedeniyle ağırlıklı dış finansman kaynakları ile büyüme politikalarına yönelmişlerdir. 1931 yılında Almanya'da baş gösteren finansal sıkıntı ise temelde iki unsura bağlanmıştır. 1924-1931 arası kuralsız bankacılık işlemlerinin artışı istikrarsız bankacılık alanı yaratmıştır. Dönemin bankalarının işlem politikaları öz sermaye ve likiditenin güvence altına alınmasını sağlayan bir mekanizma olmadan büyüme yönlüydü. Ulusal bankacılık sahasında Berlin kökenli büyük bankalarının aralarındaki kredi satış rekabetinin artması hisse senedi işlemlerindeki spekülatif hareketleri hızlandırmıștır. $\mathrm{Bu}$ sürece uluslararası kredi piyasaları istikrarsızlığının eklenmesi Alman Bankaları'nın ödeme güçlüklerini artırmıştır. Alman Banka sisteminin ulusal para sahasına verdiği kredilerin net

50 Peter Coy, “Message from Vienna, 1931", in Bloomberg Businessweek, 25 Nisan-1 Mayis 2011, ss. 12-13.

51 Aurel Schubert, Credit-Anstalt Crisis 1931, Cambridge Univercity Press, 1991, ss. 710.

Sayfa/Page | 101

IGU J. Soc. Sci., 4 (1), 2017, pp. $77-127$. 
Sayfa/Page | 102

İGÜ Sos. Bil. Derg.,

4 (1), 2017, ss. 77-127. yatırımlara dönme süreci de geciktiğinden yurt dışı kredilerinin geri ödenme sürecinde ciddi tıkanıklar yaşanmıştır. ${ }^{52}$

Almanya'nın 1923 yılında altın standardına devam etmesi sonucu kredi yaratabilme becerisi sinırlı idi. Bu yüzden Alman Bankacılık Sektörü finansman ihtiyacını yabancı kredilerden sağlıyordu. 1930'lu yıllara gelindiğinde bankacılık sektöründeki mevduatların \%18'ini kısa vadeli yabancı tasarruflar oluşturmaktaydı. ${ }^{53}$ Almanya'nın iki büyük bankası Dresdner ve Danatbank Amerika'dan gelen büyük kredilerle ulusal yatırımcılarına borç vermeye başladılar. Bu iki banka aldıkları dış kredi karşılığında öz sermaye değerlerinin çok üstünde ödünç işleminde bulundular. Dresdnerbank öz sermayesinin \%23 katını, Danatbank ise \%39 katını ödünç vererek kredi piyasasında yüksek risk değeri yarattılar. Bu yüksek risk değerinin engelleyecek kanuni düzenleme Alman Bankacılık Sisteminde de bulunmamaktaydı. 1929 New York Borsası çöküşüyle Alman Bankacılık Sektöründeki büyüme süreci Amerikalı kreditörlerin paralarını geri çekmesiyle aniden durmuş ve zayıf öz sermaye yapısına sahip Alman Bankaları'nın ödeme zorlukları yaşamasına neden olmuştur. Grafik 5 19231933 arasında Alman Bankacılık Sistemindeki kredi genişlemesini ve geri çekilişini ulusal finans sektörünün likit değerlerini öz sermaye gücüyle birleştirerek göstermektedir. ${ }^{54}$

\section{GRAFIK 5: 1923-1933 Alman Finans Sektörü Verileri}

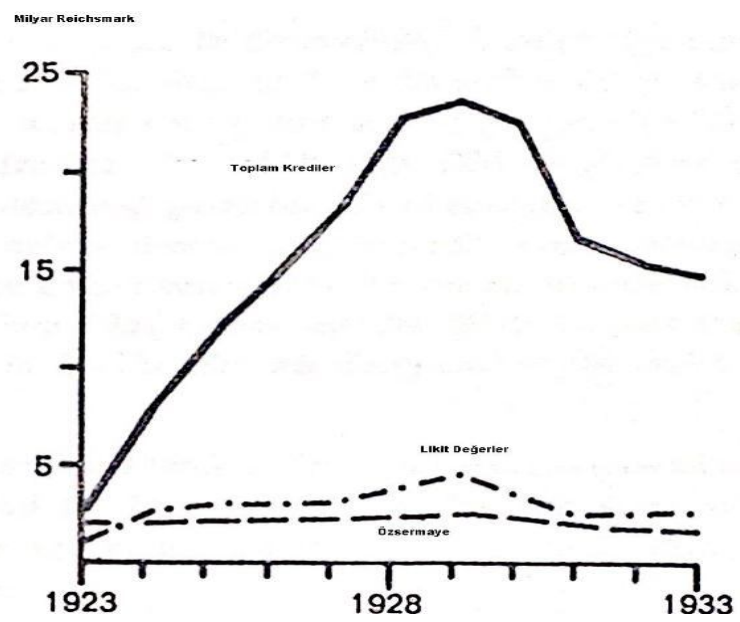

Kaynak: Heinrich Irmler, “Bankenkrise und Vollbeschaftigungspolitik (1931-1936)”, in Wahrung und Wirtschaft in Deutschland 1876-1975, Deutsche Bundesbank Publikation, 1976, s. 98.

52 Friedrich Wilhelm Henning, Das Industrialieserte Deutschland 1914 bis 1992, 8. Auflage, Ferdinant Schöningh Verlag, Paderborn, 1993, ss. 97-99.

${ }^{53}$ Isabel Schnabel, "The Role of Liquidity and Implicit Guarantees in the German Twin Crisis of 1931", Journal of International Money and Finance 28, 2009, s. 3.

${ }^{54} \mathrm{KAZ}$, "Granatsplitter aus dem Alltaglichen Imperialismus: Zur Finanz und Bankenkrise", Ausgabe 222, 2011, www.kaz.online.de, ss. 60-61. 
1930 yılına kadar Alman Merkez Bankası başkanı olan Hjalmar Schacht dış kredi finansmanının yüksek risk tehlikelerine defalarca uyarı yaparak dış kredi alımlarına sınırlandırılma getirilmesini talep etmiştir. Bütün uyarı ve çabalarına rağmen bu sınırlama sadece yerel yönetimlerin uzun vadeli dış borçlanmalarında uygulama alanı bulabilmiştir. Yanı sıra 1930 Eylül'de yapılan seçimlerde Nasyonal Sosyalist Partinin parlamento içindeki milletvekili sayısını sürpriz şekilde 12'den 107'ye çıkarması yurtdışındaki kreditörlerde huzursuzluk yaratmıştır. Alacaklıların bu huzursuzluğu nedeniyle Alman Merkez Bankası yüklü miktarda altın ve döviz cinsi sermaye çıkışı yapmak zorunda kalmıştır. Alman finans sisteminden vadeli mevduatların çoğunun geri dönmesi 1931 Haziran ayında krediler ve ödemeler dengesinde ciddi tıkanmalar yaşatmıştır. ${ }^{55}$ Bu yüzden iki yıl içindeki büyük altın rezervleri çıkışı sonucunda Alman ekonomisi durgunlaşmaya başlamış ve artan işsizlik, para arzının çarpıcı bir şekilde daralması ve fiyatların tepetaklak olmasıyla beraber ekonomi derin bir resesyonun sürecine girmiştir. 1931 yılındaki kriz öncesi politik sebeplere dayalı iki ayrı finansal istikrarsızlık süreci yaşanmıștır. İlki 1929 ilkbaharında savaş tazminatları görüşmelerinin kesilmesinden duyulan endişe ve ikincisi ise Eylül 1930 seçimleri öncesi Temmuz ayındaki hükümet krizinin finansal istikrarsızlık yaratmasıdır. Dönem içindeki diğer bir krizde ise Almanya'nın en büyük ikinci sigorta şirketi FAV AG'nin iflas etmesiyle bir dizi banka kapanmak zorunda kalmış ve makroekonomik büyüklükler üzerinde olumsuz etkiler baş göstermiştir. 1931 krizi Almanya'da politik kargaşanın hâkim olduğu bir ortamda gerçekleşmiştir. Politik kargaşanın olduğu anda bankaların savunmasız nitelikte olduğunu içeren kötü haberlerin yayılması gelecek beklentilerini olumsuz etkilemiştir. Avusturya'nın en büyük bankası olan "Österreichische Creditanstalt" 'ın büyük zarar kayıpları olduğuna ilişkin haberlerin çıkmasıyla yapısal olarak zayıf niteliklere sahip Alman Banka sektöründe de finansal panik havası esmeye başlamıştır. Savaş tazminatlarının ödenme vadesine az zaman kala Almanya'nın ikinci büyük bankası olan "Danatbank" hakkında da olumsuz dedikoduların yayılması ek olarak panik sürecini hızlandırmıştır. Kısa sürede Almanya'nın büyük tekstil fabrikalarından olan "Nordwelle" isimli şirket için de bu tür söylentilerin dalgalanması kredi alacaklısı olan "Danatbank ve Dresdnerbank" deki mevduatların büyük bir kısmının geri çekilmesine neden olmuştur. Alman Merkez Bankası Reichbank'ın kısa süreli reeskont politikası bankaların fonlanması için çok yeterli olmamış ve Reichbank likit provizyon işlemlerini daraltmıştır. Bu durum daha zayıf bilançolu Danatbank'ın çökmesiyle

${ }^{55}$ Heinrich Irmler, "Bankenkrise und Vollbeschaftigungspolitik (1931-1936)", in Wahrung und Wirtschaft in Deutschland 1876-1975, Deutsche Bundesbank Publikation, 1976, ss. 284-285.

Sayfa/Page | 103

IGU J. Soc. Sci., 4 (1), 2017, pp. $77-127$. 
Sayfa/Page | 104

İGÜ Sos. Bil. Derg.,

4 (1), 2017, ss. 77-127.

sonuçlanmıştır. Alman Banka sistemi iki gün tatil ilan edilerek kapanmıştır. Bu banka paniğinden dolayı Alman Merkez Bankası iki gecede altın rezervlerinin \%40’ını kaybetmiştir. Banka hemen ulusal paranın altına çevrilme işlemini durdurarak sermaye kontrolünü düzenleme yoluna gitmiştir. 1931 Alman Bankacılık krizi önceki diğer ülkelerde yaşanan krizler gibi ekonominin genişleme ve patlama sürecini içeren bir yapıya sahip olmuştur. Kısa vadeli yüksek dış borçlarla finanse edilmeye çalışılan bayındırlık harcamaları özellikle bankacılık sektöründe sermayenin ani geri çıkışı ile hem bankacılık sektörünü hem de ulusal parayı zayıflatmıștır. Büyük Depresyon sonrası kamu yetkileri bankacılık sektöründe de devletin bu tür kriz dönemlerinde tam garanti sağlayacak kurtarma planlarının gerekliliğine işaret etmişler ve ulusal bankaların üzerindeki denetim ve düzenlemeler yoğunlaşmıştır. ${ }^{56}$

Alman Bankacılık Sistemindeki kriz diğer ülkelerdeki bankacılık ve finans krizlerindeki gibi para kurumlarının öz sermayeleri ve likit değerleri üzerinde kredi yaratabilme becerilerini yeniden politika yapıcılarına sorgulatmıștır. Aynı zamanda ülkedeki politik yönetim değişikliğinin etkilerini de göz önüne sermiştir. Dönemin Alman Hükümeti'nin siyasi zayıflığı da krizin derinleşmesinde önemli bir rol oynamıștır. Kriz döneminde dikkat çekilmesi gereken bir husus da geriye çekilen yüklü Amerikan sermayesinin yanında Alman sermayesinin de Almanya sınırlarının dıșına akmasının gözden kaçırılmış olmasıdır. Almanya'dan çıkan ulusal sermaye Almanya'ya yabancı mevduatlar formunda ödünç olarak tekrar verilmiştir. Bu durum Almanya'nın hem altın tabanlı ulusal para hem de yabancı para cinsi sermayesinin yabancı kreditörleri alarma geçirmesine neden olmuş ve ulusal sermaye daralmıştır. Ulusal bankacılık alanındaki düzenlemeler 1931 Mayıs'ında başlamış ve toplum fertlerinin ellerindeki nakit dövizler Alman Merkez Bankası'na satılmış aynı zamanda döviz cinsi alış veriş yapımı yasaklanmıştır. Alman Hükümetinin altı aylık yurt dışı borç ödemeleri ise kesintiye uğramıştır. ${ }^{57}$

1929 Büyük Depresyon gerek Amerika gerek Avrupa kıtasında birçok ülkenin bankacılık ve finans sisteminde önemli kırılmalar yaratarak finansal krizler tarihinde "ilk büyük hegemonik kriz" olarak tanımlanmıştır. Bu kriz sınıflar ve iktisadi mekanizmayı yukarı iten üst sınıflar arasında iktisadi büyümenin doğal sınırlarının ötesinde genişleme talebinden kaynaklanan hegemonik mücadelenin sonuçları olarak tanımlanmalıdır. Süreç uzunluğu ve çoklu yönlerinden ötürü yapısal krizlere örnek teşkil eden Büyük Depresyon 'Neo-Liberalizm ve Amerikan Hegemonyası' için etki alanı en geniş hegemoni krizine örnek olmuştur. Tarihi standartlara göre düşük karlılık oranlarının yaşandığı bir dönemde gerçekleşen Büyük Depresyondaki dikkat çeken bir

${ }^{56}$ Isabel Schnabel, a.g.m., s. 4.

${ }^{57}$ H.J.Braun, The German Economy in the Twentieth Century, Routledge Publishing, 1990, ss. 67-68. 
faktör de yaşandığı yüzyılın teknik organizasyon dönüşümüyle beraber işletmecilik ve şirketleşme yapısı devrimlerinin aynı anda gerçekleşmiş olmasıdır. Finansal mekanizmanın bașta Amerika ve diğer bütün gelişmiş sanayi ülkelerinde kontrolsüz bir genişleme süreci içine girmesi bankacllık ve benzeri işletme sayısı oldukça artmıştır. Bu durum 1929 Büyük Depresyonu ve sonraki oluşan krizlerin dikkat çekici özelliklerinden bir tanesidir. Amerika ve diğer ülkelerde dönem içinde finansal sektörün ve makro ekonomik istikrarı sağlayacak kurumsallaşma ve mekanizmalar yayılımının finansal işletmecilik ve teknik inovasyon yayılımının altında kalması da yine Büyük Depresyonu tetikleyen unsurlardan bir tanesidir. Buna ek olarak kredi ve parasal alanda istikrarı sağlayacak kurumsallaşmaya ve finansal mekanizmanın ılımlı genişlemesine karşı yüksek bir direncin varlığı da bu çöküşü hızlandırmıştır. Süreç analizine sosyolojik irdeleme ile devam edilirse 19. yy.'dan itibaren sınırsız karlılık ve yüksek gelir elde etme arzusu ve akımı makroekonomik regülasyon tabanının kusurlu gelişiminde etkili olduğunu Büyük Depresyonla ispatlamıştır.58

Amerikan Merkez Bankası Başkanlığı'nı iki kez üst üste yapan Ben Bernanke 1995 yılındaki çalışmasında "Büyük Depresyonu anlamak" ifadesini makroekonominin kutsal kâsesi olarak tanımlamıştır. Büyük Depresyonun çoklu yönleri kendisine böyle bir sönmeyen şöhret kazandırmıştır. Mamafih Büyük Depresyonun nedenleri hakkındaki tartışmalar ve çözüm önerileri eş zamanlı olarak 2. Dünya Savaşı sonrası yeni bir uluslararası ekonomi ve para sisteminin sıkıntılı biçimde belirginleşmesini zorunlu hale getirmiştir. Büyük Depresyonun açıklanmasında genel bir özet yaparsak 1960 yıllarından sonra literatür taramalarında Friedman ve Schwartz'ın Büyük Depresyonu parasal şoklar tabanlı açıklamaları ön plana çıkmıștır. 1970'li yıllarda ise Tobin, Peter Termin gibi teorisyenler grubu yatırım ve tüketim harcamalarındaki otonom azalışları gerekçe olarak görmeyi tercih ettiler. Her iki grup da Amerikan ekonomisi odaklı çalışmalarla bu sonuçlara ulaştılar. 1980'li yıllarda ise Büyük Depresyon hakkında uluslararası karşılaştırmalı yeni bir yaklaşım doğdu ve kendisinden önceki iki tartışma grubuna ait görüşleri ortadan sildi. Başta Ben Bernanke'nin sayılabileceği Büyük Depresyon'un 'Yeni Konsensüs' yaklaşımı Ben Bernanke'nin aşağıdaki ifadeleri ile özetlenmektedir:

“Büyük Depresyondaki öncül neden Amerika'da yaşanan şok dalgalardır. İki Dünya Savaşı arası gösterdi ki 1930 başlarına doğru dünya çapındaki parasal sınırlamaların fazlalığı üretimin azalışına neden olacak bir pasif tepki niteliği olarak görülmemelidir. Parasal sınırlamalar daha çok birbirlerini etkileyen zayıf para kurumları, kısa vadeli politika yapımı ve tahmin edilemez politik ve iktisadi önkoşulların sonucudur."

${ }^{58}$ Dominique Levy, Gerard Dumenil, Crisis of Neoliberalism, Harward University Press, 2011, ss. 265-278.

Sayfa/Page | 105

IGU J. Soc. Sci., 4 (1), 2017, pp. 77-127. 
Sayfa/Page | 106

İGÜ Sos. Bil. Derg.

4 (1), 2017,

ss. 77-127.

20. yy.'ın ilk yarısında gümrük birlikleri ve uluslararası ticarete dayalı iktisadi bütünleşme üzerinde önemli çalışmalar yapan Jacop Viner Büyük Depresyonun oluşumunda büyük sanayi güçlerinin 1920'li yılların ikinci yarısından itibaren dünya fiyatlarını deprese ettiklerini ve depresyonun tabanını hazırladıklarını ileri sürmüştür. Amerikan Merkez Bankası'nın 1929 ortasından sonra oluşturduğu sıkı para politikası önlemleriyle efektif talep yetersizliği yaratarak Depresyonu derinleştirdiğini savunmuştur. Amerikan Merkez Bankasının Depresyonun başlangıcıyla beraber ilk dört yıl enflasyon pratiği yapmamasını eleştirmiştir. Yaşadığı dönemin temel iktisadi hakim düşüncelerine aykırı gelen bu fikirlerine rağmen Viner Depresyonun sadece ulusal faktörlere bağlı kalınarak açıklanamayacağını da ilave etmiştir. Ona göre dünya genelindeki daraltıcı ekonomi politikaları da uluslararası ekonomik ilişkileri zayıflatmış ve bu yüzden Amerika dışındaki diğer ülkeler de derin bir depresyona girmiştir. Nitekim bu görüş ilerde Peter Termin ve Barry Eichgreen'in desteklediği uluslararası kurumsal koordinasyonun tabanını oluşturmuştur. 1922 Cenova Ekonomi Konferansı sonrası Klasik Altın Standart Sisteminden Altın-Kambiyo Sistemine geçiş bazı ülkeler tarafından tercih edilmeyişi nedeniyle sağlıklı işlemesi engellenmiştir. Viner'e göre para sistemindeki kusurlu yapı neticesinde altın ve para stokunun \%70 gibi yüksek bir kısmının Fransa ve Amerika'da toplanması uluslararası para ve ticaret politikalarında sapmalar yaratmıştır. Bu düşüncesine rağmen Viner altın kambiyo sisteminin varlığını Büyük Depresyon'un açıklanmasında etkili bir faktör olarak görmemiştir. Bilakis altın kambiyo sistemini destekleyerek döviz kurlarının istikrar sağlayıcı özelliğinin kurumsal sistemin ana mekanizma parçası olarak sürdürülmesini dünya ekonomisi geneli için gerekli olduğu ileri sürmüștür. Uluslararası ticaretin canlanması ve deniz aşırı yatırımların hızlanmasıyla Amerika ve diğer ülke ekonomilerinin bir an önce kendine gelmesini sağlayacak para ve ticaret sistemi önlemlerinin alınmasını şiddetle tavsiye etmiştir. ${ }^{59}$

Büyük Depresyonun açıklanması 20. Yüzyılın para sistemleri tarihçesi içinde hakim olan neoklasik sentezin sınırları içinde şekillenmiştir. $\mathrm{Bu}$ sentezin içinde öncelikle para arzı şokları, faiz elastikiyetiyle oluşan tüketim ve yatırım talebindeki sıralı değissimler ve sermaye akımları kavramları sıklıkla incelenmiştir. Bu sentezler içinde Büyük Depresyonu tanımlamada Frederic Mishkin literatüre yeni bir bakış getirerek aksak finansal piyasalar tanımını katmış bir iktisatçıdır. Mishkin 1976 yılındaki çalışmasında borç deflasyonu faktörünün tüketici talebinin sürekli zayıflamasında etkisinin olduğu bir model yaratmıştır. Araştırmalarında sermaye piyasası noksanlıkları

${ }^{59}$ Sebastiona Nerozzi, "From the Great Depression to Bretton Woods: Jacop Viner and the International Monetary Stabilition", European Journal History of Economic Thought, 18/1, 2011, ss. 55-63. 
olarak sermayenin yeniden dağılım sürecindeki kusurların ve yüksek kaldıraçların depresif etkileri üzerinde vurgulama yapmıştır. $\mathrm{Bu}$ şekilde finansal faktörlere dayalı literatürde önemli bir görüş farklılığı yaratmıștır. Farklı bakış açılarıyla incelenen 1929 Büyük Depresyon modern makroekonomi için her defasında yeni dersler çıkarmaktadır.60

Dikkatli bakılırsa 1929 Büyük Depresyon ve Çöküşün gerekçeleri farklı açılardan irdelenmekle beraber hiç biri tek başına tatmin edici net bir sebepsonuç ilişkisi verememiştir. Bu açıdan 1929 Amerikan Borsası Çöküşü ve yarattığ kriz akabinde nedenleri ve önlem tedbirlerinin sunulmasındaki çalışmalar ilgi çekici entelektüel bir yapboz oyununun parçaları haline gelmiştir. Dönemin ekonomistleri ise yenilikçi iktisadi fikirler yaratarak şöhretlenme sürecine girmişlerdir.61

\section{1929 BÜYÜK DEPRESYONDAN 2008 KÜRESEL FINANS KRİİNE}

2008 Krizi 2007 yılında geri ödenmeme riski yüksek alt gelir grubuna yönelik krediler olarak tanımlanan subprime kredi krizi olarak başlamıştır. Amerika'da 2000 yılı başında teknoloji şirketlerine ait hisse senetlerinin balon etkisi yaratması ve arkasından gelen 11 Eylül saldırıları ekonomiyi durgunluk sürecine sokmuştur. Bu durgunluğun aşılması için ikinci el konut piyasası üzerinden yeni finansal araçlar yaratılarak ekonomi canlandırılmaya çalışılmıştır. Finans kuruluşları faiz oranlarının da inmesinden cesaretlenerek daha yüksek riskli ipotekli konut kredi satışlarına yönelmişlerdir. Bu durum konut fiyatları balonları yaratmakla kalmamış aynı zamanda reel değerlerin çok üzerinde dünya genelinde yüksek küresel likidite yaratmıştır. Geleneksel yatırım araçlarındaki getiri riskli ipotekli konut kredileri üzerine dayalı yeni finansal türevlerin getirisinden düşük olduğu için yatırımcılar daha çok risk üstlenip yüksek getiri elde etme peşinde koşmuşlardır. Riskli kredi alacaklarının tahsili yavaşlayamaya ve kesilmeye başladıkça da finansal kazanç düzeni iflas etmiştir.62 Bu sürecin analizini ise Walter Bagehot'a ait 'Lombard Street' isimli eserinde görebilmekteyiz. Ona göre finansal alanda gizli bir örtü içinde bütün koşullar her katılımcının lehinde giderken piyasada içinde bir aracı kurum ya da bankanın zayıflaması ve borçlarını çeviremez hale gelmesi finansal piyasalarda tedirginlik ve şüphe yaratacaktır. Oluşan bu şüpheler bankacılık sektörünün tümüne olan güvencin yok olmasına neden

${ }^{60}$ Charles W. Calomiris, "Financial Factors in the Great Depression", Journal of Economic Perspectives, Volume 7, Number 2, Spring 1993, ss. 61-80.

61 Micheal Bordo \& Harold James, "The Great Depression Analogy", NBER Working

Paper Series, Working Paper 155584, December 2009, www.nber.org/papers/ w15584, s. 4.

${ }^{62}$ Hüseyin Ali Kutlu, Savaş Demirci, “Küresel Finansal Krizi (2007-?) Ortaya Çıkaran Nedenler, Krizin Etkileri, Krizden Kısmi Çıkış ve Mevcut Durum”, Muhasebe ve Finansman Dergisi, Ekim/2011, ss. 122-124.

Sayfa/Page | 107

IGU J. Soc. Sci., 4 (1), 2017, pp. 77-127. 
Sayfa/Page | 108

İGÜ Sos. Bil. Derg.,

4 (1), 2017, ss. 77-127.

olacaktır. Bankaların hangisinin ne kadar kötü durumda olduğunun bilinmemesi 2007 yılının sonunda finans sisteminin felç geçirmesine neden olmuştur.63 Özet olarak 2000'li yıllardaki gevşek para, kredi, mali ve regülasyon politikaları emlak fiyatlarının patlamasına, kaldıraç oranlarının yükselmesine ve nihayetinde ipotek balonlarının çökmesine neden olmuştur. Risk yönetim prosedürlerinin zayıf regülasyonu ile 'gölge bankacılık' sektörünün kontrolsüz şekilde büyümesi krizle son bulan 'çökecek kadar büyük bir o kadar da başarısız' finansal saha yaratmıştır. ${ }^{64} \mathrm{Bu}$ sonuçların ışığında 2000'li yıllar sonrası yaşanan iktisadi olaylar zinciri göz önüne alındığında 2008 Finansal Krizin normal bir konjonktürel dalgalanmanın doğal bir düşüş süreci veya varlık balonlarının standart bir patlama evresi olarak görülmesi kabul edilmiş bir düşünce olmamıștır. Bu uzun vadeli kriz ekonomi tabanlı olmakla beraber bunun dışındaki politik tercih tabanlı faktörleri de ön plana itmiștir. ${ }^{55}$ Buna ek olarak devletin regülasyon yetkisinin zamanla kaybolmaya başladığı Milenyum Yüzyılında aynı zamanda regülasyon ve denetim kurumlarının kendilerine yönelik inançlarının da zayıfladığı görülmüştür. Amerikan Merkez Bankası Başkanların konut balonlarına ve kaldıraç oranlarından kaynaklanan aşırı borçlanmaya rasyonel faiz politikaları ile uzun bir dönem müdahale etmemeleri politik tercihli kararlar olarak nitelendirilmelidir. Aynı dönemde regülasyon kurumları, finansal kurumların aşırı büyümesiyle batmalarına engel olabilecek hiçbir ciddi tedbir almamışlardır. Piyasa tabanlı finans aktörleri finansal kurumlarının kendi kendilerini denetleme yaparak daha iyi bir finans regülasyonun sağlanacağını bile ileri sürmüşlerdir.66

2008 Krizi geçmiş tarihi krizlerin birçoğuna özellikle 1929 Büyük Depresyonuna dikkat çekerek üzerine yoğunlaşılmasına neden olmuştur. 2008 Kriziyle beraber finansal krizler tarihinin eski defter yaprakları açılmaya başlanmış ve 20. Yüzyılın süreklilik ve etki alanı genişliği nedeniyle gelecekte oluşacak bütün finansal krizlerin mihenk taşı sayılacak 1929 Büyük Depresyon 2008 Krizi ile ilişkilendirilmeye çalışılmıştır. Mevcut çalışmaların bir kısmında her ne kadar 1929 büyük Depresyon Milenyum Yüzyılının 2008 ilk Finans Kriziyle eş değerlendirme içine sokulsa da 1929 Büyük Depresyon kendisinden sonra gelmiş ve gelecek bütün krizler için zayıf bir örnekleme olacaktır. Çünkü Büyük Depresyon döneminin koşulları ile bugünün koşulları

${ }^{63}$ Nouriel Robuni, Stephan Mihm, “Kriz Ekonomisi”, Pegasus Yayınları, 2012, ss. 95-96.

${ }^{64}$ Richard S. Grossman \& Christopher Meissner, "International Aspect of the Great Depression and The Crisis of 2007: Similarities, differences and Lessons", Oxford Review of Economic Policy, Volume 26, No: 3, www.elsevier.com, 2010, s. 332.

65 Jeffrey Friedman, "Capitalism and The Crisis. Bankers, Bonuses, Idealogy and Ignorence" in What Caused the Financial Crisis, Edited by Jeffrey Friedman, University of Pennsylavia Press, 2010, ss. 1-2.

${ }^{66}$ Fırat Demir, "Büyük İstikrar Döneminden Büyük Durgunluk Dönemine: Krizdeki Kapitalizm veya Kriz Kapitalizmi", Ülke Deneyimleri Ișığında Küresel Kriz ve Yeni Ekonomik Düzen, der. Fikret Şenses ve diğerleri, İletişim Yayınları, 2013, ss. 125-126. 
birbirinden oldukça farklılaşmıştır. Buna rağmen Büyük Depresyon döneminde yapılan iktisat politikaları hataları günümüze kadar sıklıkla tekrar edilerek oluşan başarısızlıklar kritik politika değişimlerinin hangisinin sert depresyonlara karşı daha etkili olabileceği konusundaki belirsizliği daha da artırmıştır. Bunun de nedeni günümüz ekonomisi 1929 yılına göre daha geniş sayıda finansal inovasyonlar ve kurumsal çeşitlilik içeren karmaşık bir yapı içindedir. Bu karmaşık yapıya rağmen günümüz ileri kapitalist ülkelerin para otoriteleri geçmişe göre daha esnek ve seri hareket edebilmektedir. Ama bu esneklik ucuz kredi politikaları ile pompalanmış ekonomilerin hep aynı sonla karşılaşmalarına da neden olan faktörlerden bir tanesidir. Bıraktığımız 20. yy. içinde ucuz para ve kredi politikalarının finansal alan risklerini kolaylaştırarak artırdığını da gözlemekteyiz. Ülke ekonomilerini hareketlendirecek finansal kolaylıklar açık pozisyonları artırarak krizin dünyanın farklı bir köşesinden hızlıca yayılmasına da neden olabilmektedir. Fakat bu kriz süreçlerinin sıklığı ve sertliği asla kapitalizmin sonu olarak değil tam tersine gelişimi olarak algılanmalıdır.67

1929 Büyük Depresyon koşulları her ne kadar 2008 Finansal Kriz koşulları ile birebir örtüşmese de finans krizlerinin mihenk taşı olarak görülen 1929 Büyük Depresyon'dan elde edilen tecrübelerin 2008 Finansal Krizi için ne kadar faydalı olabileceği literatürde en sıklıkla irdelenen araştırma konusu olmuştur. Zira bıraktığımız yüzyıl içinde 2008 Krizini karşılaştırabileceğimiz ve sonuçlar türetebileceğimiz yegâne kriz örneği 1929 Büyük Depresyon'dan başkası değildir. 2008 Finansal Krizi ile 1929 Büyük Depresyon ve sonrasında yaşanan krizler arasında bir eşleştirme yaptığımızda bazı benzerlikleri ve farklılıkları belirleyebiliriz. 2008 Finansal Krizi öncekilere benzeten süreçler şöyle özetlenebilir. Kriz öncesi bir dizi ülkede varlık fiyatları yüksek bir tırmanışa geçmiştir. Gayrimenkul fiyatları kriz öncesi \%30'luk bir artışla son 18 ay içinde zirve yapmıştır. Gelişmiş birçok sanayi ülkesindeki uzun süreli kredi genişlemesinin yarattığı banka ve para krizleri gelişmekte olan piyasalara da yansımıştır. $\mathrm{Bu}$ piyasalarda da emlak fiyat patlamaları yaşanmıştır. Kredilerin hızlı büyümesi daha çok tüketicilerin aleyhine gelişmiştir. Daimi yükselmekte olan emlak fiyatlarına yetişmek için ek likidite ihtiyaçları artmış ve borç yükleri artışı kredi piyasasındaki sistematik riski tehlikeli sınırlara getirmiştir. 2008 Finansal Krizini öncekilerden ayıran farklılığı ise dört açıdan ele alınabilir. 2008 Krizinde şeffaf olmayan ve daha karışık finansal araç geniş bir alana yayılmıştır. Finansal alanda Amerika merkezli ulusal ve uluslararası birbirine bağlılık daha kısa sürede ciddi bir artış göstermiştir. Finansal kurumların kaldıraç oranları keskin bir şekilde hızlanmıștır. Bu krizde tüketici sektörü merkez rol oynamıștır. Ağırlıklı olarak riskli ipotek kredilerinin limit değerlerinin aşılmasından kaynaklanmaktadır.

${ }^{67}$ Richard Pomfred, "The Financial Sector and the Future of Capitalism", Economic System, 34, www.elsevier.com/locate/ecosys, 2010, ss. 22-37.

Sayfa/Page | 109

IGU J. Soc. Sci., 4 (1), 2017, pp. $77-127$. 
Sayfa/Page | 110

İGÜ Sos. Bil. Derg.

4 (1), 2017, Ss. 77-127.

Birçok Avrupa ülkesinde de tüketicilerin borç-gelir oranları hızla yükselmiştir. $\mathrm{Bu}$ artışla finansal sektördeki çözülme reel sektöre de yansımıştır. Daha önceki kriz dönem verileri ile karşılaştırma yapıldığında geçmiş dönem krizlerinin ekonomik aktivite değerlerinin daha büyük ve uzun sapmalar gösterdiği tespit edilmiştir.68

2008 Finansal Krizi sadece 1929 Büyük Depresyon ile dar alanda karşılaştırıldığında benzerlikler ve farklılıklar olarak şu sonuçlara ulaşabiliriz. Benzerlikler açısından sıraladığımız da her iki kriz döneminde de uzun dönemli ticaret hacmi daralmaları göze çarpmaktadır. Büyük Depresyon sürecinde 1929-1932 arası uluslararası ticaret hadleri 27 öncü ülkede yarı yarıya kayıpla gerçekleşmiştir. 2008 sonrasında ise dünya ticaret hadleri $\% 20$ azalış göstermiştir. Her iki krizde de kendinden önceki selefleri gibi makroekonomik büyüklük balonları patlaması yaşanmıștır. Krizler ağırlıklı Amerika içinde yaşanmasına rağmen birçok sanayi ve yükselen pazarlarda derin etkisini göstermiştir. Oluşum ve gelişim süreçleri açısından her iki kriz de benzerlikler olmasına rağmen 1929 Krizi oldukça zayıf bir savunma sistemini içeren finansal sahada gerçekleşmiştir. Finansal istikrarın sürmesinde yetkili olan kurum ve organizasyonların çoğu o dönemde bulunmamaktaydı. Etkinliği olmayan regülasyon ve denetim vardı. Mevduat sigorta fonları oluşturulmamıştı. Son ödünç veren kurum olarak Merkez Bankaları 1929 yılında tecrübesiz ve cesaretsizdiler. Birçok açıdan Büyük Depresyon politika yapıcılarına önemli dersler de vermiş oldu. Politika yapıcıları krizlere müdahale etme aşamasında daha hızlı ve etkin davranmak zorunda olduklarını anladılar. Hükümetlerin ve Merkez Bankalarının sıra dıșı eylem veya söylevlerinin aynı Büyük Depresyondaki gibi hızlı bir çöküşe neden olacağı daha kesinleşmiştir. Bunlara ek olarak 2008 Krizi Japonya, Avrupa ve Amerika para otoritelerinin daha uyumlu iş birliği içinde koordinasyonlu çalışma gerekliliğini de ortaya koymuştur. ${ }^{69}$

Krizler öncesi ülkelerde yaşanan emsal olaylar serileri karşılaştırılarak benzerlikler bulunmaya çalışılmıştır. 1929 Büyük Depresyon öncesi Amerika dışındaki birçok sanayi ülkesinde \%25'lere varan GSYİH azalışları, çalışan nüfusun yine aynı oranlarda emek piyasasının dışında kalması ve reel ücretlerin \%30'lara varan kaybı bu emsal olaylar zincirindeki en dikkat çeken ortak özelliklerden olmuştur. Bir başka emsal olay benzetmesi 1929 sonrası Almanya'nın resesyon süreci ile 1994 Meksika Peso Krizi arasında kurulmuştur. Her iki ülke de çevrilmesi mümkün olmayan yüksek borçlarından ötürü uzun dönemli bir resesyonla baş etmek zorunda

${ }^{68}$ Stijin Claessem, Ayhan Köse ve Marco E. Terrones, "The Global Financial Crisis. How Similar? How Different? How Costly?", Journal of Asian Economics, www.elsevier.com, 2010, ss. 248-264.

${ }^{69}$ Richard S. Grossman, Christopher Meissner, a.g.m., ss. 324-330. 
kalmışlardır. 1931 yılında Avusturya'da başlayan Almanya üzerinden yayılan Avrupa kıtasındaki finansal kriz 1997-1998 yıllarının 'yükselen pazarlar' krizinin modern bir yansıması olarak algılanabilir. Detaylı bir incelemede 1931 yılında Merkez Avrupa ve Almanya'daki bankacılık sistemindeki güven probleminin yarattığı krizin borç yönetimleri üzerindeki sermaye kontrollerini oldukça zorlaştırdığını görmekteyiz. Bu durum karşısında İngiltere altın cinsi ödemelerini durdurmak zorunda kalmıştır. Böylece 1929 Krizi Atlantik ötesi ülkelerde de sıralı paniklerle devam etmiştir. Böyle bir emsal olaylar zincirinin etkileri 1997 yılında Güney Kore, Tayland ve Endonezya'nın 100 Milyar Dolar cinsi ödemelerini durdurmasıyla da yaşanmıştır. Asya ülkelerinin paraları Dolar karşısında hızlı değer kaybı içine girerken Asya'daki yeni yükselen pazarların varlıklarına olan güvenç kaybolmuştur. Bu güvenç kaybı 1998 Rusya ve iki yıl sonra Arjantin'de kriz faktörü olarak kendini göstermiştir. Bu tür emsal olaylar zincirlerinin karşılaştırması her ne kadar tam bir kesinlik içermese de 1929-1932 yılları arası birbirini tetikleyen olaylar zinciri bıraktığımız 20. Yüzyıl içinde 1994 Meksika Peso Krizi ile yeniden başlamış, arkasından 1997 ve 1998 Rusya krizi ile devam etmiştir. Yeni Milenyum Yüzyılında ise 2000 yllından itibaren şişirilen borsa balonlarının patlamasıyla 2008 Küresel Finans Krizi gerçekleşmiştir. ${ }^{70}$

2000'li yıllara doğru son 20 yıl içinde birbirinden bağımsız olmakla beraber benzer yönleri bulunan başka finansal krizler de yaşanmıștır. 1990’lı yıllarda sanayi ve yükselen pazar ekonomilerinde finansal kurumlar, bankalar ve gölge bankacılık niteliğindeki aracı kurumlar uzman yatırım danışmanlığı niteliğinde varlık satışları işlemlerini yoğunlaştırmışlardır. Fakat bu davranışlarından ötürü regülasyonun zayıf olduğu birçok ülkede varlık balonları patlamaları yaşanmıștır. Bu tür varlık balonları kaosunu yaşayan ülkelerden bir tanesi Japonya'dır. 1986-1991 yılları arasında Japonya'da bu tür spekülatif akımlar konut fiyatları dahil bir çok varlık fiyatını ortalama \%140 civarında artırmıştır. "Zombi Bankacılık" olarak denilen bu anlayışın kötü sonuçlarını Japonya ileriki yıllarda derinleșen deflasyon baskısı ile hissetmiştir. Japonya'nın kendi içinde yaşadığı bu kriz bir sonraki 1997 Asya Krizi ile olan bağımlılığı tartışılsa da şişirilmiş kredi ve para balonlarının zincirleme etkileri birkaç yıl aralarla farklı ülkelerde görülmüştür. ${ }^{71}$ Yakalanma şekilleri farklı olsa da 1997 Asya Krizi ile 2008 Küresel Finans Krizi de bazı açılardan benzerlikler göstermiştir. Asya Krizinde bölgeye yüklü miktarda sermaye akımları dolar tabanlı borç enstrümanları sayesinde gelmiştir. Bu sayede Asya Bankaları özvarlıklarının çok üzerinde borç-kredi

\footnotetext{
${ }^{70}$ Liaquat Ahamed, "Lord of Finance-The Bankers Who Broke the World", The Penguin Press, 2009, ss. 438-440.

${ }^{71}$ Assaf Razin \& Steven Rosefielde, "Currency and Financial Crisis of the 1990's”, CESifo Economic Studies, Volume: 57, www.oxfordjournals.org, 3/2011, ss. 503-508.
}

Sayfa/Page | 111

IGU J. Soc. Sci., 4 (1), 2017, pp. 77-127. 
Sayfa/Page | 112

İGÜ Sos. Bil. Derg.,

4 (1), 2017, ss. 77-127.

sarmalına girmişlerdir. Dikkat edilirse her iki krizde de kriz öncesi ilgili bölgeye yüklü sermaye akımları gelmesiyle emlak fiyatları astronomik balonlara neden olmuştur. Ucuz kredi kanallarının çoğalmasıyla da kaldıraç değerleri riski yükselmiştir. Malezya ve Asya Krizi'nde zayıf bilançolu bankaların ve finansal kurumların oldukça yüksek bir kaldıraç oranı ile işlem yapmalarının yaratacağı sonuçlar oldukça net anlaşılmıştır. Böyle bir sürecin sonunda küresel finans serbestliği hareketine aykırı bulunsa da Malezya Hükümeti yeni buluşlarla donatılmış bir sermaye akımına karşı kendisini yasal düzenlemelerle korumak zorunda kalmıştır. Her iki krizi sürecinde finansal saha erken uyarı sinyalleri aslında ortak nitelik göstermiştir.72

2000'li yıllar civarında görülen meta piyasaları patlamaları ve iflaslarının arkasında meta üreticileri ve tüketicilerinin yarattıkları pazar manipülasyonları ve vadeli işlemler piyasasındaki spekülatif hareketler olduğu inancı oldukça yaygındır. $\mathrm{Bu}$ yüzden bu tür patlama ve iflaslar neticesinde oluşan krizleri anlamak için vadeli işlemlerdeki sözleşmelerin güncel spot fiyatları neden yukarı doğru ittiği araştırılmıştır. Meta patlamaları ile iflaslarda vadeli spot fiyatlar arası ilişkinin dışında metaların dar bir bölgede üretilirken geniş coğrafik bir alanda tüketime sokulmasına dikkat çekilmiştir. Araştırmalarda anahtar temel değişkenler olarak tarım ve enerji ürün fiyat değişimlerinin vadeli işlemler piyasasını șekillendirdiği ve doğrudan spot fiyatlarına yansıdığı belirlenmiștir. Endeks spekülatörlerinin meta fiyatlarını zirve seviyelere itekledikleri gözlenmiștir. Gününüzde anlaşılmıştır ki meta fiyatları ders kitaplarındaki temel arz-talep dengesinden ciddi bir ayrışma içindedir ve spot fiyatlar artık vadeli işlem fiyatları tarafından belirlenmektedir. Gelecekteki fiyatlar alıcı ve satıcıların hedge ettikleri fiyat risklerine göre etkilenirken klasik spekülatörler sadece kısa vadeli fiyatlar üzerindeki etkili olabilmişlerdir. Mevcut araştırmalar varlık ve meta fiyat balonlarının üzerine dayalı parasal bir ekonomi yaratmanın uzun vadede getireceği maliyetler üzerine önemli ipuçları vermiştir. ${ }^{73}$

Krizlerin önceden tahmin edilebilirliği için izlenen öncü göstergelerin ne kadarının sağlıklı bir öngörü oluşturacağına dair görüşler farklılaşmaktadır. Hiçbir göstergenin tam bir netlik ifade etmemesine karşın bir takım göstergelerin sağlıklı öngörü için faydalı olacağı da aşikârdır. İlgili çalışmaların bir kısmında krizlerin tahmin edilebilmesine olanak sağlayan ortak altı tane değişken göze çarpmaktadır. Bunlar sırası ile GSYIH değişimleri, endüstriyel

72 Rohana Othman, R. Abdulaziz, Isa Ibrahim, "A Perspective on the Subprime Crisis 2007: Lessons to be Learnt in Relation to the Asian Financial Crisis 1997", European Journal of Economics, Finance and Administrative Sciences, Issue 23, www.eurojournals .com, 2010, s. 103.

${ }^{73}$ L. Randall Wray, "Money Manager Capitalism and The Global Financial Crisis", The Levy Economics Instute Working Paper Collection, Nr: 578, www.levy.org, 2009, ss. 1618. 
üretim, ulusal paraların depresyon değeri, sermaye piyasası performansları, nakit rezerv kayıpları ve bir IMF programına katılım durumu gibi değişkenler olarak sıralanmaktadır. İncelenen bu değişkenler içinde uluslararası rezerv kayıpları krizlerin tahmininde kullanılacak en faydalı gösterge olmuştur. Reel döviz kurlarının aşırı değer değişimleri de para piyasası çöküşünün tahmininde kullanılan popüler bir gösterge niteliğinde çımıştır. Daha dolaylı bir etki alanı olarak tasarruflar ve kısa vadeli dış borç ödeme yükümlülükleri artışları da krizin oluşabilme olasılığını artıran faktörler olarak göze çarpmaktadır. ${ }^{74}$

Küresel Finans Krizi'nin oluşumuna yönelik öngörüler ise krizi tahmin etme öngörü faktörlerine göre oldukça daha geniş bir yelpaze içinde yayılmıştır. Alan Blinder 2007 yaz sonrası finansal karışıklığın oluşmasına neden olan problemli dönemin ana hatlarını şöyle sıralamaktadır:

1. Özellikle konut balonları ile şişirilmiş varlık ve kıymetli evraklar balonlarının varlığı,

2. Finansal sistemdeki yüksek kaldıraç oranları,

3. Finansal regülasyonların zayıflığı, hem yasaların daha az regülasyonlu finansal alan yaratma girişimleri hem de mevcut regülasyonların yükümlülüklerini etkinsiz biçimde yerine getirme çabaları,

4. İpoteğe dayalı ve risk primi yüksek kredilerde hatalı bankacılık işlemleri,

5. Riski yüksek ipotekler üzerine dayalı regülasyonsuz vadeli işlemler ve varlıkların gelişigüzel oluşturulması,

6. Derecelendirme şirketlerinin kötü performansı,

7. Birçok finans ve aracı kurumdaki yüksek tabanlı ücretlendirmenin fakirliğe yol açması.

Aynı eserinde Blinder, 1997-2006 yılları arasında emlak fiyatlarının \%85'lik yüksek bir artış gösterdiğine ama 2006 sonrası bu yüksek artışın kesilmesine rağmen gayrimenkul varlık fiyatlarının artışının hızlı bir şekilde devam ettiğini belirtmiştir. Amerikan Merkez Bankası'nın 2001 yılı resesyonu sonrası beklenen toparlanmanın gerçekleşmediğinden uygulanan yeni para politikaları sonucu ipoteğe dayalı varlık senetlerinin getirisi \%6,5 oranına fırlamıștır. Fakat Merkez Bankası'nın kendi varlık senetleri getiri oranı \%4,5 seviyesinde kaldığından yatırımcılar riski önemsenmeye değmez denilen ipoteğe dayalı varlık senetlerine hücum etmişlerdir. Yurt içi ve dışı bir sürü yatırımcının yeni kazanç alanına yığılması varlık balonlarının tehlike arz edecek limitlere ulaşmasına neden olmuştur. Bu duruma Wall Street'deki eski

\footnotetext{
74 Jeffrey Frankel, George Saraules, "Can Leading Indicators Asess Country Vulnerability? Evidence from the 2008-2009 Global Financial Crisis", Journal of International Economics, 87, www.elsevier.com/jie, 2012, ss. 216-230.
}

Sayfa/Page | 113

IGU J. Soc. Sci., 4 (1), 2017, pp. 77-127. 
Sayfa/Page | 114

İGÜ Sos. Bil. Derg.,

4 (1), 2017, ss. 77-127.

Büyük Beşli olarak adlandırılan Lehman Brothers, Bear Stearns, Merrill Lnych, Morgen Stanley ve Goldman Sachs adlı yatırım bankalarının riski yüksek kaldıraç oranları ile işlem yapması da eklenince finansal çöküş kaçınılmaz ve hasar verici şekilde gerçekleşmiştir. Gerçekleşen bu olaylar zinciri Wall Street sınıfının 2007-2008 Krizini küresel finans sisteminin 'Minksy Anı' olarak adlandırmalarına neden olmuştur. ${ }^{75}$

2008 Küresel Finans Krizi öncesi Konut balonları üzerine dikkat çeken isimlerden bir tanesi de Avusturya ekolünden gelen iktisatçı Kurt Richebächer'dir. Asya Krizi'ni ve Brezilya ekonomisi üzerine dayalı doğru tahminleri ile kendini gösteren Richebächer 2008 Finansal Kriz öncesi şu yorumda bulunmuştur:

“Görüşüme göre temel risk dev gibi büyüyen konut balonlarının yaklaşan patlamaları olacaktır. Konut sahipleri varlık portföylerinin aksine toplumun ağırlıklı doğal elemanlarıdır. Konut balonlarının çatlaması 2002 yılında baş gösteren varlık fiyatları çöküşünden daha zarar verici olacaktır zira konut balonları daha geniş bir Amerikan kitlesinin canını acıtacaktır. Aynısı akabinde tahvil ve sermaye piyasası için de geçerli olacaktır. Diğer bir risk ise Dolar'ın kendisidir."

Richebächer finansal serbestliğin uzun vadede büyüme ve kaynakların dağılımı için en ideal yol olduğunu savunmakla beraber finansal baskıların tabanında nakit akımlı bir ekonomiden varlığa dayalı menkul kıymetler tabanlı ekonomiye itilmişliğin yattığını ileri sürmüştür.76 Ona göre Keynesyen kuramcllar finansal baskıları artıracak nitelikte durumu daha kötüleştirmişlerdir. Adam Smith'den beri tasarruflar gelirin harcanmayan kısmıdır ve bütün dillerde aynı ifadeyi içerir. Bu tanımdaki anahtar nokta, gerçek anlamdaki tasarruflar sadece kaynakların yönünü tüketim malları üretiminden sermaye mallarının üretimine kaydırabilen özelliğe sahip olanlardır. Richebächer günümüz tasarruflarının gerçek anlamda tasarruflar niteliğinde olmamasından ötürü balon ekonomilerinin yaratıldığını savunmuştur.77

2008 Finans Krizi'nin arkasında dikkat çekici bir şekilde şişirilmiş varlık fiyatlarının varlığının olması kriz öncesi Amerika dâhil birçok ülkede bankacılık sektör kazançlarının yükselmesine yol açmıștır. Ama finansal aracılık hizmetindeki karlılık oranları ise oldukça düşük seyretmiştir. Yeni ve

75 Alan Blinder, After the Music Stopped, The Financial Crisis, The Response and The Work Ahead, The Penquin Press, 2013, s. 34-39, 48, 52, 70.

76 Kurt Richebächer, “An Unprecendented Speculative Spree”, Richebächer Letters-23

March 2007, www.safehaven.com/author/kurtrichbcher/51.

77 Manuchehr Shahrokhi, "The Global Financial Crisis 2007-2010 and The Future of Capitalism", Global Finance Journal, no 22, www.elsevier.com, 2011, s. 201. 
farklılık yaratan yatırım bankacıllğı anlayışı sonucu bilanço şişkinlikleri ile yüksek kazançlar elde edilirken finansal sektörün reel varlıkları ile borç yükümlülükleri arasında vade riskleri uyuşmazlık göstermeye başlamıştır. Bunun bir sonucu olarak büyük yatırım bankalarının kaldıraç oranları kontrolsüzce artmıștır. Yatırım bankacılığı ve aracı kurumların tabanını oluşturduğu Gölge Bankacllılık sistemindeki regülasyon ve denetim eksiklikleri ve ipoteğe dayalı kredi piyasasındaki esnek ödünç standartları ve gölge bankacılık sisteminin likidite sıkışıklığında ihtiyacı olan fonları klasik bankacılık sistemindeki gibi son ödünç veren kurum olan Merkez Bankalarından yeteri kadar temin edememeleri Küresel Krizi tetikleyen etmenler arasındadır. 5 Kasım 2008 tarihinde İngiliz Kraliçesi'nin The Telegraph gazetesine verdiği demecinde 'Niye hiç kimse bugüne kadar kredi sıkışıklığının farkına varamadı?' sorusu krizin olası nedenlerini açıklamaya çalışanlar için en zor cevaplandırılacak soru olmuştur. ${ }^{78}$

2008 Finansal Krizi üzerinde en dikkat çekici sorunlar, Gölge Bankacılık Sistemi, regülasyon zayıflığı ve kısa ve yüksek risk alınan varlık piyasası, derecelendirme şirketlerinin birbirleri ile çatışan menfaat ilişkileri ve reel ekonomiyi tehlikeli bir patlama noktasına getirecek kontrolsüz karmaşık yapılı finansal varlık yayılımı olarak özetlenebilir. Gölge bankacılık sistemi üzerindeki zayıf regülasyon risk alma davranışlarını kışkırtarak 'başarısız olacak kadar büyük' ifadesine uygun bir finans alanı yaratmıştır. Bu krizin Amerikan merkezli olmasının gerekçesi ülkedeki finansal buluşların herhangi bir regülasyon ağından geçmeden yayılması ve benimsenmesi ile finans denetimcilerinin sistemi etkin düzenlemedeki yetenekleri arasındaki açık farktan kaynaklanmaktadır. Gölge bankacılık içinde yer alan yatırım bankaları diğer aracı kurumlar gibi öz sermayelerinin çok üzerinde kısa vadeli yüksek kaldıraç oranlı varlıklara sahip oldular. Bu kurumlardan bazıları hedge fonlama sayesinde şişirilmiş varlık portföyleri ile işlem yapmaya devam ettiler. Bu şekilde gölge bankacılık kurumları borç yükümlüklerinin üstünü daha iyi örtebilmişlerdir. Bu kriz regülasyon kurumlarının bütün finans işletmelerine yönelik sorumluluklarını daha net göstermiştir. Finans kurumlarının kendi kendini regülasyon yöntemlerinin gelecek dönem krizlerde yeterli olamayacağı inancını kuvvetlendirmiştir. Kendi kendini regülasyon politikalarının ancak Kanada gibi yeni finansal buluşlara fazla itibar etmeyen klasik finans yapılı ülkelerde işleyebileceğini göstermiştir. Amerika gibi finansal yeniliklere daha cesaretli davranan ülkelerde ise kendi kendine içsel regülasyon yönteminin riskleri algılamada yetersiz olacağı ispatlanmıştır. Așılmaya çalışılan son kriz kredi derecelendirme kurumlarının da regülasyon sürecine sokulmalarını gerekli hale getirmiştir. Krizle beraber

${ }^{78}$ Ricordo Cabral, "A Perspective on the Symptons and Causes of the Financial Crisis", Journal of Banking and Finance, Volume 37, www.elsevier.com/locate/jbf.,2013, s. 103-104.

Sayfa/Page | 115

IGU J. Soc. Sci., 4 (1), 2017, pp. 77-127. 
Sayfa/Page | 116

İGÜ Sos. Bil. Derg.,

4 (1), 2017, ss. 77-127.

bir tarafta kamu menfaati diğer tarafta yatırım ve ipotekli kredi veren bankalar ile derecelendirme kurumları arasında derin bir çatışma olduğu ortaya çıkmıştır. Kredi derecelendirme kurumlarının gelirlerinin müşteri varlık portföyler değerleri ile doğru orantılı olması bu kurumların müşteri odaklı hizmet verebilme ihtimallerini artırmakta ve bu tür aldatıcı menfaatler çatışması altında alınan önlemlerin Amerika'daki gibi etkin olmadığı anlaşılmıştır. $\mathrm{Bu}$ yüzden regülasyon odaklı yapısal problemlerde Merkez Bankaları'nın finansal kriz ateşini söndürecek rolü ön plana çlkmaktadır. Merkez Bankaları'nın regülasyon ve denetim yetkilerinin artırılmasına yönelik düşünceler yaygınlaşmakla beraber bunu diğer görevleri ile nasıl entegre halinde sürdürecekleri konusunda endișeler de yaratmıștır. 1929 Büyük Depresyon deneyiminden sonra Merkez Bankaları'nın fiyat istikrarı ve tam istihdam hedefleri doğrultusunda hareket etmeleri sürerken son yirmi yıl içinde enflasyon hedeflemesi görevleri daha ağır basmaktadır. Bu koşullar altında Merkez Bankaları'nın yeni yükümlülüklerini kendi içinde mi yoksa ayrı bir ünite altında daha etkin gerçekleștireceği sorusu güncelliğini korumaktadır. Merkez Bankası'nın finansal sistemi regüle edici görevi ile fiyat istikrarı hedefini aynı anda sürdürebilmesine ilişkin şüpheler vardır. Zira bu iki amaç arasında Merkez Bankası varlık fiyatlarının denetimini de üstlenmiş olacaktır. Bu koşullar altında Merkez Bankası enflasyon hedeflemesine yönelik faiz politikası geliștirirken varlık fiyatları ve faiz oranları üzerinde de denetim gücünü nasıl şekillendirecektir sorusu teknik açıdan net cevaplanmamaktadır. İkili amaç doğrultusunda rasyonel bir faiz politikası yürütmek oldukça zor gözükmektedir. Merkez Bankaları'nın bağımsızlık pozisyonu da bu tür yeni yükümlükte zayıflayabilecektir. Krizin zayıflamaya başladığı bir dönemde devam eden mali yardımlar kamu borcunu artırarak enflasyonist süreci tırmandıracaktır. Böyle bir durumda Merkez Bankaları enflasyonist sürece daha hoş görülü yaklaşmak ve devlet ekonomisi ile bağımsız bir anti enflasyonist politika arasında seçim yapmak zorunda kalacaklardır. Bu durum bağımsızlıklarını zedeleyecektir.

Cuikerman'a göre gelecekteki hiçbir regülasyon reformu aşağıdaki kriterleri sağlamayacaktır:

I. Bütün finansal sistemin regülasyonu ve denetimi sağlanmalıdır. Regülasyonda bulunan kurumların sorumluluk sınırları imtiyazlara imkân vermemelidir.

II. Regülasyon kurumları arasındaki bilgi akımlarında sızıntı olmamalıdır.

III. Merkez Bankaları'nın regülasyonla yükümlü ünitesi makro ihtiyatlı regülasyon yapabilecek merkezi ve bağımsız pozisyonda olmalıdır. ${ }^{79}$

${ }^{79}$ Alex Cuikerman, "Reflections on the Crisis and on its Lessons for Regulatory Reform and Central Bank Policies", Journal of Financial Stability, No:7, www.elsevier.com,

2011, ss. 27-34. 
2008 Finansal Kriz daha karmaşık yapılı hale gelen finansal yeniliklerin dengesiz yayılımı sonucu risk faktörlerini artırdığını göstermiştir. Şayet küresel risk haritası dünya çapında etkin bir kredi kayıt sistemi ile takip edilebilirse bankaların finansal sistemdeki risk değerleri oldukça şeffaf bir şekilde izlenebilir. Böylece finans kurumlarının içinde oluşabilecek riskler önceden tespit edilebilir. Makro sağduyulu gözetim ve denetim yükümlügüne sahip kurumlar küresel kurallar çerçevesinde önlemler alabilir ve uygulattırabilir. Makro ihtiyatlı gözetim ve denetimlerin sürekliliği ve dikkat edilecek kriterlerin esnetilmeden izlenmesi bir sonraki olası bir krizin engellenmesi veya olası hasarın en aza indirgenmesi için önemli olacaktır. Böyle bir sürecin varlığı ise ancak her ülke finans alanı için geçerli olacak ortak küresel kurallar ve makro ihtiyari gözetim ve denetim yükümlülüğünü saygın bir şekilde yürütecek kurum veya kurumların ışığında gerçekleşecektir.

Finansal sistem içinde sübjektif risk problemleri arttıkça son kriz sonrası farklı öneriler tartışmaya açılmaktadır. İlk önerilen uygulanabilirliği oldukça zayıf olmakla beraber finans kurumlarının boyutları ve aktivitelerine sınırlamalar koymaktır. Daha inandırıcı bir öneri ise finans kurumlarının sermaye ve likit varlıkları üzerinde katı düzenlemelerin yapılmasıdır. Örnek olarak finans kurumlarının toplam varlıklarının yüzde onuna denk gelecek teminatlı bono ihraç etmelerine izin verilmesidir. $\mathrm{Bu}$ büyüdükçe artan kırılganlık probleminin tam çözümü olmasa da finans kurumlarını potansiyel şoklar karşısında kuvvetli tutacaktır.

Milenyum Yüzyılının başındaki kriz gerek finansal sektörü gerekse kapitalizmin dayanıklılığını daha sorgulatır olmuştur. Bu kriz aynı zamanda serbest pazara duyulan güvenci de azaltmıștır. Şüphesiz mevcut sistem başka boyutlu yeni bir kriz yaşanmadan hayatta kalmaya devam etmelidir zira bulunduğumuz konumda mevcut sistemin yerine geçerek ayakta kalacak alternatif bir sistem mevcut değildir. Daha geniş kapsamlı bakımdan geçirilmesi gereken bir finans sistemine ihtiyacımız olduğu aşikârdır. Bu sistem aynı zamanda uzun bir dönem geçmiş finansal krizlerle bir daha karşılaştırma yapılmamasını da garanti altına almalıdır. Sistemi reforme edenlerin ise kısa ve dar alanlı şahsi menfaatlerden arınmış olması gereklidir. 80

Mevcut sistemin sorgulanmasının arkasında finansal piyasa katılımcllarının davranış analizleri de önemlidir. Katılımcıların panikleme, depresyon eğilimli olmaları ve sürü etkisi hareketleri ile finansal çılgınlıkların yarattığı kısa kazançlar peşinde koşmaları ekonominin patlama dönemlerinde

80 Otmar Issing, "Some Lessons from the Financial Market Crisis", International Finance, 12/3, www.eurojournals.com, 2009, ss. 432-438.

Sayfa/Page | 117

IGU J. Soc. Sci., 4 (1), 2017 , pp. 77-127. 
Sayfa/Page | 118

İGÜ Sos. Bil. Derg.,

4 (1), 2017,

ss. 77-127.

aşrı risk almalarına neden olmaktadır. Volatilitenin arttığı dönemlerde daha fazla risk alma isteği dalgalanma ve çöküş süreçlerini yayarak hızlandırmaktadır. Karşılıklı güvenin çökmesi varlık satışlarını tepe noktalara getirerek piyasadaki likiditenin aniden buharlaşmasına neden olmaktadır. $\mathrm{Bu}$ tür olayların bir daha tekrarlanmaması için öncelikle Amerika'da denetim ve gözetim mekanizmalarının ciddi bir revizyona ihtiyacı olduğu ön görülmüştür. Bu ön görüye yönelik ilk hamle Amerikan Kongresi'nin Temmuz 2010 yılında yürürlüğe soktuğu "Dodd Frank Wall Street Reform Yasası" ile beraber kurulan "Finansal Hizmetler Konseyi" olmuştur. Konsey denetim ve gözetim yükümlülükleri olan kurumlar arasında koordinasyonu sağlamakla sorumlu olmaktadır. Bu süreçte Amerikan Merkez Bankası makro ve mikro sağduyulu denetim ve gözetim görevini üstlenmiştir. Amerika dışında kalan finansal alan hâkimiyeti için Uluslararası Bankacılık Denetleme Komitesi ile Amerikan Merkez Bankası'nın BASEL 3 kriterleri altında ortak makro sağduyulu politikaların da aktifleştirilmesi mevcut sistemin revizyonu için öngörülenler arasındadır. Fakat bu tür bir işbirliğinde makro sağduyulu denetimlerin sistematik risk yönetiminde para politikaları ile nasıl bir etkileşim içinde olacağı tartışma konusudur. Para politikalarının araçlarının ne genişlikte sistematik risklerin azaltılmasında nasıl koordine edileceği ise netleşmemiş küresel tartışma konusu olarak devam etmektedir. ${ }^{81}$

Krizin sorgulanmasında Amerikan Bankacılık Sisteminin BASEL kurallarının çoğunu tamamlamamış olması küresel finans sisteminin odağında bulunan bir ülkedeki zayıflık olarak nitelendirilmektedir. Böyle bir eksikle Amerikan yatırım bankaların ekonomik hızlanmayı artırabilmek için çıkarttıkları yeni finansal ürünler çok yıpranmış ikinci el araba ticaretine (lemon trade) benzemektedir. Bu tür araçların satışında satıcı aracın kusurunu bilmesine rağmen aracı kusursuz bir araba fiyatından satmayı hedefler. Bu yüzden iyi kullanılmış olan araçların fiyatı asla kusurlu araçların fiyatı üstüne çıkamaz. İyi konumdaki 2.el araçlar kendi sahipleri tarafından kullanırken yıpranmış 2. el araçlar ise kusurlarıyla beraber piyasa malı olarak işlem görürler. Amerikan Finans Sektöründe de bu tür kusurlu finansal ürünler ağırlık kazanırken klasik ve güvenli finansal ürünler piyasa dışına itilmiştir. 2008 Küresel Finans Krizinin tabanında kusurlu finansal ürün ticaretinin yoğunluk kazanması krizi tetikleyen nedenlerden dikkat çekici olanıdır. Yatırım bankalarının ve gölge bankacılık sisteminin de mevduatları riski ve faiz oranı daha yüksek kusurlu finansal varlıklara yöneltmesiyle krizi çıkartacak tehlikeli bir kumar alanı yaratılmıştır. ${ }^{82}$

81 Janet L. Yellen, "Macroprudential Supervision and Monetary Policy in the Post-Crisis World", Business Economics, Volume: 46, no: 1, www.eurojournal.com, 2011, ss. 3-10. ${ }^{82}$ Hans Werner Zinn, Casino Capitalism, How the Financial Crisis Came About, What Needs to be Done Now, Oxford University Press, 2010, ss. 92-93. 
Küresel finans sisteminin istikrarına yönelik geliştirilen fikirlerin gelecekteki bir krizi önleyici nitelikte kesinlik içermemesi kapitalizmin algılanmasında yeni boyutlar yaratmıştır. Amerika'daki ekonomi alanlı yayınlarda 20. yy.'dan itibaren işletme kapitalizminin küresel finansal kapitalizme dönüştüğü sıklıkla vurgulanmıştır. Kimi yazara göre de kapitalizmin bu aşaması monopolist finans kapital evresi olarak tanımlanmaktadır. Finans artık üretken kapitalizmi yeniden yapılandırma becerisine sahip bir güç olarak kendini ispatlamıştır. Böyle bir yaklaşımı Amerika'daki finans ve finans dışı gelirleri karşılaştırarak anlamak mümkün gözükmektedir. 2004 yılında Amerika'daki reel sektör gelirleri 534 Milyar \$ iken finans sektörü gelirleri 300 Milyar \$'ın üzerine çıkmıştır. Finans sektörü gelirlerin reel sektör gelirlerine yakınlaşması her ne kadar reel sektör üzerinde itici güç niteliğinde olsa da finans sektör gelirlerinin dengesiz ve kontrolsüz dağılımı bir o kadar sistematik riskleri de yanında getirmektedir.

Finansal krizin kökenlerinin araştırılmasında Amerika ve Avrupa ekonomisi dışında kalan 2000'li yılların yeni ekonomik ve politik güçlerini dikkate almak lazımdır. Zira son on yılda küresel üretim değerlerinin $\% 50$ 'den fazlası gelişen piyasalardan elde edilmiștir. Uluslararası denetim ve danışmanlık hizmeti veren kurumların geleceğe dönük araştırmalarında Brezilya, Çin, Hindistan, Endonezya, Meksika, Rusya ve Türkiye'nin oluşturacağı E-7 tanımlı ülkelerin 2050 yılında günümüz G-7 ülkelerine göre \%25 daha büyük bir ekonomiye sahip olacağı ve küresel ekonominin büyümesini kontrol edebilme becerisinde olacağı ileri sürülmektedir. Bu tür çok kutupluluk görüşü ise daha büyük bir finansallaşma ile kırılganlık olasılığını taşıyacak yeni küresel krizlere açık kapı bırakmaktadır. Sürece Ortadoğu petrollerinde yüzyıldır hak sahipliğini bırakmayan 'Yedi Kız Kardeşler' tanımlı Batılı petrol şirketlerine Rusya, Çin, Brezilya ve Malezya gibi gelișen ülkelerin yeni petrol devlerini ortak olarak eklenmeleri de göz ardı edilmemelidir. 2008 Finansal Kriz Amerikan'ın nispi güç kaybından dolayı yeni güç merkezlerinin oluşmasına ve gelecekte kaynakların azalarak ekolojik krizlerin çıkmasına yol açacaktır. Bu yüzden gelecek krizlerin petrol, tarım ürünleri ve su kaynaklarının bölüşümü üzerine dayanması kaçınılmaz gözükmektedir. ${ }^{83}$

\section{SONUÇ}

19. yy. başlarından itibaren küresel para ve finans sistemi içinde dünya ekonomisini büyük sıkıntılara sokan para ve finans tabanlı krizler yaşanmaktadır. Sanayi Devrimi sonrası sıklaşan krizlerin küresel ve finans sisteminin daha sıkı entegrasyonu ile yayılım etkisi de artmıştır. Bu krizler

83 Willam K. Tabb, "Four Crisis of the Contemporary World Capitalist System", Montly Review, Volume 60, Issue 05, www.monthlyreview.org, 2008, ss. 44-55.

Sayfa/Page | 119

IGU J. Soc. Sci., 4 (1), 2017, pp. $77-127$. 
Sayfa/Page | 120

İGÜ Sos. Bil. Derg.

4 (1), 2017, ss. 77-127.

dünya ekonomisi içinde yer alan ülkelerin birbirleri ile olan ticari ve finansal ilişkileri arttıkça daha hasarlı ve uzun vadeli nitelik kazanmışlardır. Yaşadığımız yüz yıla kadar yaşanan finansal krizler oluşum gerekçeleri açısından benzer özelliklere sahip olmasına rağmen iki ayrı evrede incelenmesi daha doğru olacaktır. Her iki evredeki küresel koşullar ve iktisat öğretisindeki ayrışmalar krizlerin oluşum ve engellenmesine yönelik çözüm önerilerini farklılaştırmıştır.

18. yy.'dan 1930'lu yıllara kadar yaşanan finansal krizler ve panikler ortak kurallara bağlı olmayan, denetim ve gözetim yetkisini eline almamış ulusal para kurumlarının varlığı altında gerçekleşmiştir. Zira ilk evrede küresel para, finans ve krediler sistemini denetleme, gözetleme ve yönlendirme yapabilecek ulusal veya uluslararası kurumların noksanlığı mevcut idi. Bu yüzden para ve kredi kurumları kendi sermaye güçlerinin üzerinde kredi yaratabilme olanaklarına sahiptiler. Küresel finans düzeni içinde yer alan para aktörlerinden herhangi birinde baş gösteren kredi geri ödeyememe durumu panik yaratmış ve diğer para aktörlerinin de domino etkisi ile birbirlerine yakın aralıklarla krizler yaratmalarına neden olmuştur. Pazarın üstünlüğü ilkesine dayalı iktisat öğretisi içinde bu tür panik ve krizler de yetkili bir para kurumunun yapabilecekleri oldukça sınırlıdır. 1929 Büyük Depresyon'a kadar hâkim olan Klasik İktisat Öğretisi içinde pazarın üstünlüğü anlayışı para ve finans sahasını yönlendirecek yetkili kurumların müdahale tecrübelerini uzun bir süre kısıtlamıştır. İkinci evre de ise Keynesyen Devrimle iktisat öğretisindeki yeni yapılanmalar küresel para ve finans sistemini şekillendirebilecek yetkili mekanizmaların kurulmasına olanak sağlamıștır. İkinci evreyle beraber 20. yy. içinde ulusal ve ya uluslararası para kurumları finansal krizleri engelleyebilecek tecrübe kazanmışlardır. Para, kredi ve finans politikalarının sınırlarını keşfetmeye başlamışlardır. Fakat bu evredeki krizler ilk evredeki krizlere göre farklı nedenlerden ötürü ortaya çıkmaktadır. İlk neden olarak küresel finans sistemini elinde tutan ulusal parası kuvvetli hakim ülkelerin hatalı para ve kredi politikaları sonucu kendi içlerinde gerçekleşen ekonomik dalgalanmalarını örnek verebiliriz. Günümüzde küresel finans sistemini elinde tutan hegemonik bir ülkenin neden olduğu konjonktürel bir dalgalanma, diğer ülkelerde resesyonlara ve krizlere neden olabilmektedir. İkinci neden ise küresel sermaye hareketlerinin Yükselen Pazarlar olarak tanımlanan ülkelere kontrolsüz ve eşit olmayan bir dağılımla, giriş ve çıkış yapmasıdır. Yükselen Pazar olarak tanımlanan bir ülkeye reel sektör gücünün üzerinde giren dolaysız sermaye yatırımları belli bir dönem sonra tehlike arz ederek varlık balonları yaratabilir. Bu varlık balonlarının patlaması sermaye girişi yapılan ülkeyi ve bu ülkeye yatırım yapan diğer ülkeleri finansal krize sürükleyebilir. Ne var ki böyle bir kriz sürecinde mücadele yöntemleri oldukça yetersiz kalmaktadır. Zira 20. yy. içinde krizlere karşı kazanılmış tecrübeler küresel finans sistemin yeni türev araçlarla daha karmaşı hale gelmesine sebep olmuştur. Buna karşın krizlerle mücadelede 
halen klasik para ve finans politikası araçları kullanılmaktadır. Bu yüzden önümüzdeki olası krizlerde mücadele yöntemlerimiz ve araçlarımız etkisini yitirmektedir. Milenyum Yüzyllında krizlerle mücadele yöntemleri ve araçlarda bir değişiklik olmadığı varsayımı altında finansal krizlerin daha sert ve uzun vadeli geçeceğini düşünebiliriz.

İçinde bulunduğumuz Milenyum Yüzyılında sadece finans ve ekonomi tabanlı değil aynı zamanda bunların dışında kalan faktörlerin de etkili olacağı krizlerin varlı̆̆ı daha olası gözükmektedir. 2007-08 Finansal Kriz ile yaşadığımız bu süreci gelecekteki olası sıklaşacak krizlerden dolayı küresel kapitalizmin başarısızlığı ve kırılma noktası olarak nitelendirmek ileri sürülebilecek bir görüş olsa da problemin çözümlerini yine kapitalist sistemin inişli çıkışlı yollarında arama zorunluluğumuz yadsınamaz bir gerçekliktir. Zira elimizde şu an kapitalist sistemin yerine geçecek alternatif öneri veya öneriler demeti olmadığından, en iyi seçenek kapitalist finans sektörü ve hatta uluslararası nitelik kazanmış reel sektör yapısının hiçbir özel veya kurumsal kişiliğe ayrımcılık yapmadan ulus üstü yasalar ve yeni kurumlar ile düzenleyen mekanizmaları kurmaktır. Bu mekanizmalar aynı zamanda yeni nesil kriz mücadele ve araçlarını da barındırmalıdır. Mekanizmaları işletecek ve içinde bütün ülkelerin temsilcilerini kapsayacak bir organizasyon uluslararası makro ihtiyari denetim ve regülasyon yapabilen tek yetkili olarak görevlendirilmelidir. Çünkü bu tür geniş yetkileri ulusal Merkez Bankaları, Amerikan Merkez Bankası gibi kurumlara bırakmak teknik ve politik açıdan zayıflıklara neden olacaktır. Küresel finans sisteminin sağlıklı geleceği için geniş katılımlı bir finans regülasyon konsorsiyumunun alacağı kararlar finansal alanın geneline hitap ederek rasyonel kararlar içerecektir. Ancak bu tür geniş katılımlı finans regülasyon konsorsiyumunun kurulması küresel finans sistemini elinde tutan hegemonik kuvvetlerin ne kadar istekli olduklarıyla alakalıdır. Uzun dönemli durgunlukların aşılması için ulusal para otoritelerinin finans aktörlerini yüksek risk alımlarını teşvik edecek politikalardan uzak tutması ve finansal piyasalardaki kaldıraçlı işlemlerin geniş katılımlı uluslararası finans konsorsiyumu tarafından bütün katılımcı ülkeleri içine alacak şekilde kurallara bağlı düzenleyebilme yetkisinin varlığı finansal krizleri engelleyebilecek önlemler olarak görülebilir. Yanı sıra küresel alandaki finansal derinleşme arttıkça olası bir krizin yayılmasıyla yaratacağı etkiler daha itinalı araştırılmalı ve finansal derinleşmenin sınırları uluslararası platformda çizilmelidir.

Önümüzdeki yıllarda oluşabilecek finans krizleri için özellikle bıraktığımız son yüz yıl içinde hep aynı soru gündeme gelmiştir. "Krizler önlenemez mi?" Bu sorunun cevabı ise ya kapitalizmin lehinde ya da aleyhindeki görüşlerle açıklanmaya çalışılmıştır. Geçmişte yaşanan krizlerin hepsi, arkasından gelen krizler için tecrübe taşları olmuştur. Fakat buna rağmen görülmüștür ki büyük krizler öncesinde finansal aktörlerin ve

Sayfa/Page | 121

IGU J. Soc. Sci., 4 (1), 2017, pp. 77-127. 
Sayfa/Page | 122

İGÜ Sos. Bil. Derg.,

4 (1), 2017, ss. 77-127.

kurumların yapmış oldukları hatalar yeni hatalarla beraber elde edilen tecrübelere rağmen tekrarlanmıștır. Finans tarihindeki krizler, kapitalist evrim tarihinin tekrarından mı yoksa kişisel zafiyet tekrarından mı karşımıza çıkacaktır sorusunun tartışılmasının yerinde olacağını düşünebiliriz.

\section{KAYNAKÇA}

AHAMED, Liaquat, Lord of Finance-The Bankers Who Broke the World, The Penguin Press, 2009.

AKTAN, Coşkun Can, Hüseyin ŞEN, Globalleşme, Ekonomik Kriz ve Türkiye, TOSYÖV Yayınları, 1999.

ALLEN, Larry, " The Global Financial System 1750-2000", Reaktion Books Publishing, 2001.

BERNANKE, Ben, Harold JAMES, "The Gold Standart, Deflation, and Financial Crisis in the Great Depression: An International Comparison", NBER Working Paper No: 3488, October 1990, http://www.nber.org/papers $\angle \mathrm{w} 3488$.

BLINDER, Alan, After the Music Stopped, The Financial Crisis, The Response and The Work Ahead, The Penquin Press, 2013.

BOCUTOĞLU, Ersan, "Hyman P. Minksy'in Konjonktür Teorisi 20072010 Küresel Krizi Açılamaya Uygun mu? Heterodoks Değerlendirme”, Bankacılar, Türkiye Bankacılar Birliği Yayını, Sayı 75, Aralık 2010, s. 10 ve 14. BOIANOVSKY, Mauro, "Wicksell on the American Crisis 1907", Journal of History of Economic Thought, Vol: 33.2, 2011, www.elsevier.com, ss. 1-6.

BORDO, Micheal, Harold JAMES, "The Great Depression Analogy", NBER Working Paper Series, Working Paper 155584, December 2009, www.nber.org Lpapers/w15584.

BORDO, Micheal, Olivier JEANNE, "Boom-Busts in Asset Prices, Economic Instability and Monetary Policy", NBER Working Papers, No: 8966, www.nber.org/papers/w8966.

BRAUN, H.J., The German Economy in the Twentieth Century, Routledge Publishing, 1990.

BRUNNER, Robert F., Sean D. CARR, The Panic of 1907-Lessons

Learned from the Market's Perfect Storm, Published by John Wiley \& Sons, New Jersey, 2007.

BURKETT, Paul , "Forgetting the Lessons of Great Depression", Review of Social Economy, Spring 1994, Vol:52, Issue 1, ss. 70-71.

BURTON, Theodore E., "Financial Crises", BiblioLife, LLC Publishing, Original Copyright 1902 by D. Appleton and Company, www.books.google.com, ss. 282-283. 
CABRAL, Ricardo, "A Perspective on the Symptons and Causes of the Financial Crisis", Journal of Banking and Finance, Volume 37, www.elsevier. com/locate/jbf, 2013, ss. 103-104.

CALOMIRIS, Charles W., "Financial Factors in the Great Depression", Journal of Economic Perspectives, Vol. 7, Number 2, Spring 1993, ss. 61-80.

CALOMIRIS, Charles \& David WHEELOCK, "Was the Great Depression a Watershed for American Monetary Policy" in The Defining Moment: The Great Depression and The American Economy in the Twentieth Century, Ed. Micheal Bordo, NBER Onlinebook, www.nber.org/chapters/c6887, 1998.

CALOMIRIS, Charles W., Larry SCHWEIKART, "The Panic of 1857: Origins, Transmission, and Containment", The Journal of Economic History, Vol: 51, no: 4, 1991, ss. 808-809.

CLAESSEM, Stijin, Ayhan KÖSE, Marco E. TERRONES , "The Global Financial Crisis: How Similar? How Different? How Costly?", Journal of Asian Economics, www.elsevier.com, 2010, ss. 248-264.

COY, Peter, "Message from Vienna, 1931", in Bloomberg Businessweek, 25 Nisan-1 Mayıs 2011, ss. 12-13.

CUIKERMAN, Alex, "Reflections on the Crisis and on its Lessons for Regulatory Reform and Central Bank Policies", Journal of Financial Stability, No:7, www.elsevier.com, 2011, ss. 27-34.

DEMİR, Fırat, "Büyük İstikrar Döneminden Büyük Durgunluk Dönemine: Krizdeki Kapitalizm veya Kriz Kapitalizmi”, Ülke Deneyimleri Işığında Küresel Kriz ve Yeni Ekonomik Düzen, der: Fikret Șenses ve diğerleri, İletişim Yayınları, 2013, ss.125-126.

DESAI, Meghnad, Financial Crises and Global Governance, Routledge Publishing, 2004.

EĞİLMEZ, Mahfi, Küresel Finans Krizi- Piyasa Krizinin Eleştirisi, Remzi Kitabevi, 3.Baskı, 2009.

EICHGREEN, Barry, Harold JAMES, Golden Fetters: The Gold Standart and the Great Depression,1919-1939, Oxford University Press, 1992.

FISHER, Irving , "The Dept Deflation of Great Depressions", Econometrica, No: 1, ss. 347-349.

FORUM, Temmuz 2009, s.11, www.ku.edu.tr/ EAF/0904

FRANKEL, Jeffrey, George SARAULES, “Can Leading Indicators Asess Country Vulnerability? Evidence from the 2008-2009 Global Financial Crisis”, Journal of International Economics, 87, www.elsevier.com/jie, 2012, ss. 216230.

FRIEDMAN, Jeffrey, "Capitalism and The Crisis: Bankers, Bonuses, Idealogy and Ignorence" in What Caused The Financial Crisis, Edited by Jeffrey Friedman, University of Pennsylvania Press, 2010, ss. 1-2.

GALBRAITH, John Kenneth, Büyük Kriz -1929, (çeviren: Elif Nihan Akbaş), Pegasus Yayınları, 2009.

GROSSMAN. Richard S., Christopher MEISNERR , "International Aspect of The Great Depression and The Crisis of 2007: Similarities, differences and 
Sayfa/Page | 124

İGÜ Sos. Bil. Derg.,

4 (1), 2017,

ss. 77-127.

Lessons", Oxford Review of Economic Policy, Volume 26, No:3, www.elsevier.

com, 2010, s. 332.

HAFER, Rik W., Scott E.HEIN, The Stock Market, Greenwood Press, 2007.

HANSEN, Greg, Dimitri PADIMITRI, "Did the New Deal Prolong or Worsen the Great Depression?", Challenge, Vol:53, No:1; 2010, s.64.

HENNING, Friedrich Wilhelm, Das Industrialieserte Deutschland 1914 bis 1992, 8. Auflage, Ferdinand Schöningh Verlag, Paderborn, 1993.

HILT, Eric, "Rogue Finance: The life and Fire Insurance Company and Panic of 1826", Business History Review, 83 (Spring 2009), ss. 87-100.

HUGHES, J.R.T., The Commercial Crisis of 1857, Oxford Economic Papers, New Series, Vol:8, No: 2, June 1956, s. 194.

IRMLER, Heinrich, "Bankenkrise und Vollbeschaftigungspolitik (19311936)", in Wahrung und Wirtschaft in Deutschland 1876-1975, Deutsche Bundesbank Publikation, 1976, ss. 284-285.

IRWIN, Douglas A., “Did France Cause the Great Depression?”, NBER Working Paper No. 16350 September 2010, http://www.nber.org/papers/ w16350, s. 1, 36.

ISSING, Otmar, "Some Lessons from the Financial Market Crisis", International Finance, 12/3, www.eurojournals.com, 2009, ss. 432-438.

JAMES, Harold , "Globalizition and Great Depressions" , Foreign Policy Research Institute, Winter 2002, www.elsevier.com, ss. 128-129.

JONES, Edward David, Economic Crises, General Books, LLC, 2009.

KAZ, "Granatsplitter aus dem alltaglichen Imperialismus: Zur Finanz und Bankenkrise", Ausgabe 222, 2011, www.kaz.online.de.

KEHOE, Timothy, Edward C. PRESCOOT, "Great Depressions of the 20th Century", Review of Economic Dynamics, 5, 2002, www.idealibary.com, s.2

KINDLEBERGER, Charles Poor, Historical Economics- Art or Science, University of California Press-Berkeley and Los Angeles, 1990.

KOZANOĞLU, Hayri, Küresel Krizin Anatomisi, Agora Kitaplığı, 2009.

KUTLU, Hüseyin Ali, Savaş DEMİRCİ, “Küresel Finansal Krizi (2007-?) Ortaya Çıkaran Nedenler, Krizin Etkileri, Krizden Kısmi Çıkış ve Mevcut Durum", Muhasebe ve Finansman Dergisi, Ekim/2011, ss. 122-124.

KUTTNER, Kenneth, "Victorian Financal Crises and Their Implications for the Future", Business Economics, 2010, Vol: 45, no: 2, ss. 102-103.

LEBERGOT, Stanley, Pursuing Happines: American Consumers in the Twentieth Century, Princeton University Press, 1993.

LEPLER, Jessica M., The Many panics of 1837-People, Politics and the Creation of Transatlantic Financial Crisis, Cambridge University Press, 2013.

LEVY, Dominique, Gerard DUMENIL, Crisis of Neoliberalism, Harvard University Press, 2011.

MADDISON, Angus, The World Economy in the 20th Century,

Development Centre Studies, OECD Publishing, 1989, ss. 51-52. 
MARICHAL, Carlos, "World Financial Crises: Lessons of the Past", Finance and The Common Good/BIEN Commun, Volume II-III, 2009, ss. 37-38

McELVAINE, Robert S., "The Great Depression; America, 1929-1941", Three River Press, 2009.

MISHKIN, Frederic S., "Asymmetric Information and Financial Crisis: A Historical Perspective" in Financial Markets and Financial Crises, Edited by R. Glenn Hubbard, NBER Publishing, 1991, ss. 81-82.

NEROZZI, Sebastiano, "From the Great Depression to Bretton Woods: Jacop Viner and the International Monetary Stabilition", European Journal History of Economic Thought, 18/1, 2011, ss. 55-63.

OKTAR, Suat, Levent DALYANCI, "Finansal Kriz Teorileri ve Türkiye Ekonomisinde 1990 Sonrası Finansal Krizler”, Marmara Üniversitesi I.I.I.B.F. Dergisi, Cilt 19, 2010, s. 7.

ORPHANIDES, Athanasios, "Monetary Policy in Deflation: The Liquidity Trap in History and Practice", North American Journal of Economics and Finance, 15, 2004, s. 106.

OTHMAN, Rohana, R. ABDULAZIZ, Isa IBRAHIM, "A Perspective on The Subprime Crisis 2007: Lessons to be Learnt in Relation to the Asian Financial Crisis 1997", European Journal of Economics, Finance and Administrative Sciences, Issue 23, www.eurojournals.com, 2010, s. 103.

ÖZ, Sumru, “Kriz ve Korumacıllk: Tarih Tekerrür Edecek mi?”, TÜSİADKOÇ UNIVERSITY ECONOMIC RESEARCH.

ÖZER, Mustafa, Finansal Krizler, Piyasa Başarısızlıkları ve Finansal İstikrarı Sağlamaya Yönelik Politikalar, Anadolu Üniversitesi Yayınları, 1996.

POMFRED, Richard, "The Financial Sector and the Future of Capitalism", Economic System, 34, www.elsevier.com/locate/ecosys, 2010, ss. 22-37.

RAZIN Assaf, Steven ROSEFIELDE, "Currency and Financial Crisis of the 1990's", CESifo Economic Studies, Volume: 57, www.oxfordjournals.org, 3/2011, ss. 503-508.

RICH, George, The Cross of Cold- Money and the Canadian Business Cycle in 1867-1913, Carleton University Press, 1988.

RICHARDSON, Gary, Categories and Causes of Bank Distress during the Great Depression,1929-1933, Explorations in Economic History, Volume 44, 2007, www.sciencedirect.com, ss. 588-589.

RICHEBACHER, Kurt, "An Unprecendented Speculative Spree”, Richebächer Letters-23 March 2007, www.safehaven.com/author/ kurtrichbcher $/ 51$.

ROBUNI, Nouriel, Stephen MIHM, Kriz Ekonomisi, Pegasus Yayınları, 2012.

ROTHBARD, Murray N., America's Great Depression, Mises Institute Publishing, 5.Edition, 2000, ss. 214-215.

RÖPKE, Wilhelm, Crises \& Cycles, The Ludwig von Mises Institute Publishing, 2007.

Sayfa/Page | 125 IGU J. Soc. Sci., 4 (1), 2017, pp. 77-127. 
Sayfa/Page | 126

İGÜ Sos. Bil. Derg.,

4 (1), 2017, ss. 77-127.

SCHNABEL, Isabel , "The role of Liquidity and Implicit Guarantees in The German Twin Crisis of 1931", Journal of International Money and Finance, 28, 2009, s. 3.

SCHUBERT, Aurel, Credit-Anstalt Crisis 1931, Cambridge University Press, 1991.

SHAHROKHI, Manuchehr, "The Global Financial Crisis 2007-2010 and The Future of Capitalism", Global Finance Journal, no 22, www.elsevier.com, 2011, s. 201.

SIKLOS, Pierre L., "The Fed's Reaction to the Stock Market During the Great Depression: Fact or Artefact?", Explorations in Economic History Volume 45, 2008, www.sciencedirect.com, s. 182.

SÖNMEZ, Sinan, "Kalkınmanın Finansmanı, Emperyalizm ve Finansal Serbestlik Üçgeninde Dış Borçlanma”, Ekonomik Yaklaşım, Cilt:21, Sayı 75, s. 126.

SYLLA, Richard, R. WRIGHT, D. COWEN, "Alexander Hamilton, Central Banker: Crisis Management During the U.S. Financial Panic of 1792", Business History Review, 83 (Spring 2009), s. 61, 64-65.

TABB, William K., "Four Crisis of the Contemporary World Capitalist System", Montly Review, Volume 60, Issue 05, www.monthlyreview.org , 2008, ss. 44-55.

TERMIN, Peter , "Lessons from the Great Depression", The MIT Press, 1989.

WISMAN, Jon D, Barton BAKER, "Rising Inequality and Financial Crises of 1929 and 2008”, www.american.edu/cas/economics/s ss. 1-34.

WRAY, L. Randall, "Money Manager Capitalism and the Global Financial Crisis", The Levy Economics Institute Working Paper Collection, Nr: 578, www.levy.org, 2009, ss. 16-18.

YELLEN, Janet L., "Macroprudential Supervision and Monetary Policy in the Post-Crisis World", Business Economics, Volume : 46 no: 1, www.eurojournal.com, 2011, ss. 3-10.

YILDIRTAN, Z. Dina Çakmur, Finansal Krizler- Erken Uyarı Sistemleri, Nobel Dağıtım Yayınları, 2006.

ZINN, Hans Werner, Casino Capitalism, How the Financial Crisis Came About, What Needs to be Done Now, Oxford University Press, 2010. 


\section{Summary}

Since the 1800s, ever increasing severity of the global financial system is experiencing economic crisis. These crises after the Industrial Revolution and the closer integration of the global trading and financial system increased its influence spread. Classical economics is dominated by the 1929 Doctrine jurisdiction is quite limited until the monetary authorities to prevent the financial crisis has led to the Great Depression more common in this period of crisis. The development of Keynesian Doctrine of the intervention policy after 1930 and the new definition has expanded the jurisdiction of the Central Banking monetary authority. In this way, monetary and financial field has been primarily guided by national monetary authorities to voluntary organizations. Although not frequently experienced by the financial crisis has come to an end. 20th century financial crises have become more long-term and widespread. In particular, the financial crisis in a region under the conditions of the information age affect other regions more quickly and increases the fragility of the global financial system. The positive effects of the global cyclical weakness implemented in periods of monetary and fiscal policy loses its power in every crisis there is. So within the global financial system, the measures to be taken should include all monetary institutions. It has been given alone can not fix the global financial system of regional measures. of all countries within the system to ensure harmonious compliance with the monetary and financial system regulation will help to prevent the next financial crisis.

Sayfa/Page | 127

IGU J. Soc. Sci., 4 (1), 2017, pp. 77-127. 